\title{
Investigation of some Givetian rugose corals from the Mont d'Haurs Formation in southern Belgium
}

\author{
Marie COEN-AUBERT
}

DO Terre et Histoire de la Vie (Evolution de la Paléobiosphère), Institut royal des Sciences naturelles de Belgique, rue Vautier 29, B-1000 Bruxelles, Belgium; mcoenaubert@naturalsciences.be.

ABSTRACT. Cystiphylloides marennense n. sp., C. minimum (Wedekind, 1922), Atelophyllum emsti (Wedekind, 1922), Thamnophyllum godefroidi n. sp., Spinophyllum longiseptatum (Lütte, 1984) and Iowaphyllum sp. have been mainly collected on the south side of the Dinant Synclinorium, close to the boundary between the Lower and the Middle Givetian. Indeed, this material comes mostly from the lower part of the Mont d'Haurs Formation which is characterized by a high biodiversity. The genus Atelophyllum Wedekind, 1925 has been preferred to Mesophyllum Schlüter, 1889 and Lekanophyllum Wedekind, 1924 as the holotype of its type species Atelophyllum emsti has been figured in both transverse and longitudinal sections. A colony of Iowaphyllum is observed for the first time in the Givetian of Belgium. As a whole, the fauna of the Mont d'Haurs Formation is widely distributed in various areas of the Old World Realm (Europe, Asia and Australia). However, it shows strong affinities with the neighbouring countries of Belgium and especially with the Givetian rugose corals of the Eifel Hills, the Bergisches Land and the Sauerland in Germany.

KEYWORDS: Rugose corals, taxonomy, stratigraphy, Givetian, Devonian, palaeobiogeography.

\section{Introduction}

In continuation of the papers presented by Coen-Aubert (1999, 2000, 2002), six additional Givetian taxa of rugose corals coming mainly from the lower part of the Mont d'Haurs Formation in southern Belgium are described herein. These are the three cystimorph species Cystiphylloides marennense n.sp., C. minimum (Wedekind, 1922) and Atelophyllum emsti (Wedekind, 1922) together with Thamnophyllum godefroidi $\mathrm{n}$. sp., Spinophyllum longiseptatum (Lütte, 1984) and Iowaphyllum sp. This material has been mostly collected along the south side of the Dinant Synclinorium, between Wellin and Hotton which are situated to the east and northeast of Givet (Fig. 1). In this area, the Givetian is represented by five lithostratigraphic units which are in ascending order the upper part of the Hanonet Formation, the Trois-Fontaines, Terres d'Haurs, Mont d'Haurs and Fromelennes Formations (Bultynck \& Dejonghe, 2002). Moreover, a few specimens come from the south side of the Namur Basin and the Vesdre Massif where the Mont d'Haurs and Fromelennes Formations pass laterally into the Névremont and Le Roux Formations.
From a biostratigraphic point of view, the conodonts of the Belgian Givetian have been investigated in detail by Bultynck \& Gouwy (2002) and Gouwy \& Bultynck (2003, p. 326). According to these authors, the top of the Polygnathus timorensis Zone, which corresponds to the lower part of the Lower $P$. varcus Zone in the standard conodont zonation (Bultynck, 2007), is projected by graphic correlation $50 \mathrm{~m}$ above the base of the Mont d'Haurs Formation. The Lower/Middle Givetian boundary has been defined at this level and these correlations have been well illustrated by Narkiewicz \& Bultynck (2007, table 1) and Boulvain et al. (2011, fig. 8).

\section{Description of the outcrops}

\subsection{Les Limites quarry at Ave-et-Auffe (Wellin MC-1988-6;} Fig. 2)

The Mont d'Haurs Formation has been nearly completely excavated in the active Les Limites quarry during the late eighties and the nineties. The quarry partially filled now is situated to the south of Ave-et-Auffe and has been located and investigated in detail by Coen-Aubert $(1999,2000,2002)$. At the top of the

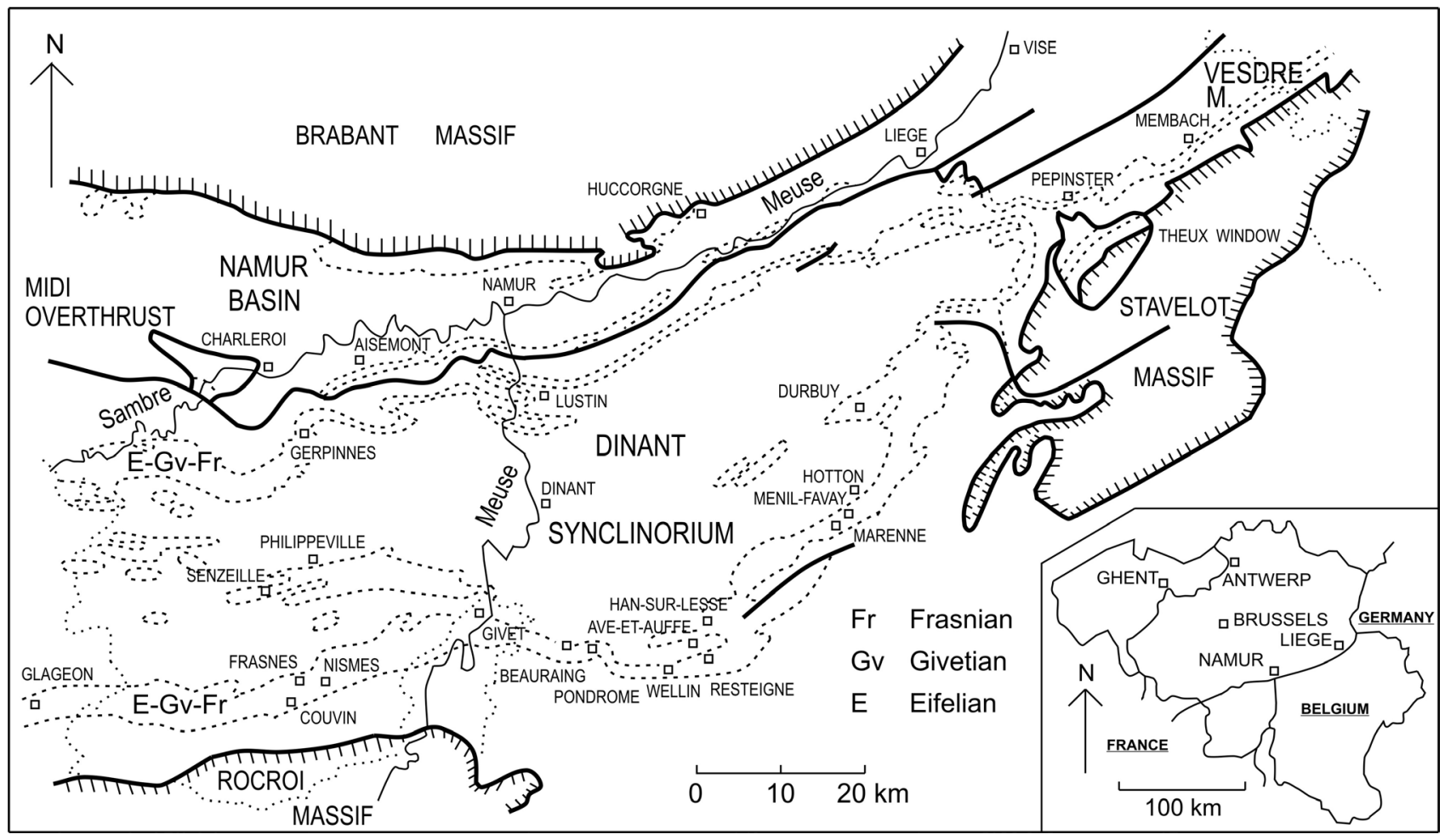

Figure 1. Geological setting and locality map in the southern part of Belgium. The borders between the countries are marked by dotted lines. The position of the Eifelian, Givetian and Frasnian is indicated by dashed lines. 


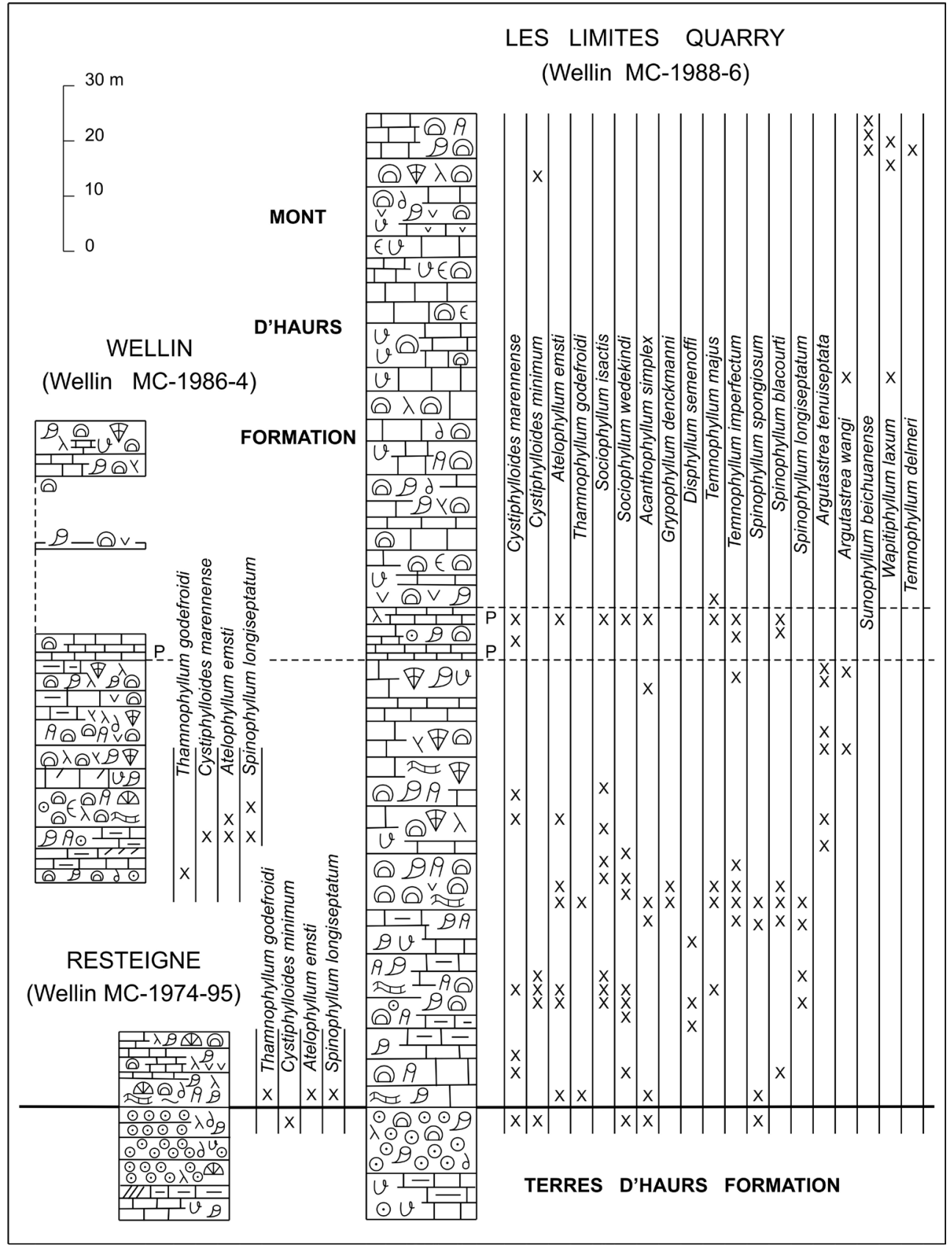

Figure 2. Comparative logs of Wellin, Resteigne and Les Limites quarries with the distribution of rugose corals. (For explanation of conventional signs, see Fig. 3).
Terres d'Haurs Formation, there are about $12 \mathrm{~m}$ of coarsely crinoidal limestones with a few stromatoporoids and corals and already some species of rugose corals characteristic of the Mont d'Haurs Formation: Cystiphylloides marennense, C. minimum, Sociophyllum wedekindi Coen-Aubert, 1999, Acanthophyllum simplex (Walther, 1929) and Spinophyllum spongiosum (Schlüter, 1889).

Then the Mont d'Haurs Formation was exposed with a thickness of about $180 \mathrm{~m}$. It can be subdivided into two parts by a double level of thin-bedded limestone which is a key bed in the area between Beauraing and Han-sur-Lesse (Fig. 1). The lower part of the Mont d'Haurs Formation is represented by rather argillaceous limestones and is often very rich in stromatoporoids and corals. The rugose coral fauna of these $91 \mathrm{~m}$ up to the top of the marker bed is highly diversified with Cystiphylloides marennense, Atelophyllum emsti, Sociophyllum isactis (Frech, 1886), S. wedekindi, A. simplex, Temnophyllum majus Walther, 1929, T. imperfectum Coen-Aubert, 2002, and Spinophyllum blacourti (Rohart, 1988). Argutastrea tenuiseptata Coen-Aubert \& Lütte, 1990 is very common in the $45 \mathrm{~m}$ below the thin-bedded limestones and is locally accompanied by $A$. wangi (Tsien, 1978). Other species such as Cystiphylloides minimum, Thamnophyllum godefroidi, Grypophyllum denckmanni Wedekind, 1922, Disphyllum semenoffi Coen-Aubert, 2000, Spinophyllum spongiosum and $S$. longiseptatum are restricted to the first $40 \mathrm{~m}$ of the Mont d'Haurs Formation.

The upper part of this lithostratigraphic unit is $89.5 \mathrm{~m}$ thick and is characterized by pure limestones with more scattered reef building organisms and a few colonies of $A$. wangi and Wapitiphyllum laxum (Gürich, 1896). At the top of this succession, the rugose corals are again abundant with $W$. laxum, fasciculate colonies of Sunophyllum beichuanense He, 1978 and rare coralla of Cystiphylloides minimum and Temnophyllum delmeri CoenAubert, 2004. This fauna is well represented at the top of the Mont d'Haurs Formation, in the Beauraing quarry where the boundary with the Fromelennes Formation has been observed (Coen-Aubert, 2004).

\subsection{Wellin quarry (Wellin MC-1986-4; Fig. 2)}

This disused quarry to the north of Wellin has also been located and described by Coen-Aubert $(1999,2000,2002)$. Below the first level of thin-bedded limestone, $40 \mathrm{~m}$ of argillaceous or rather pure limestones from the lower part of the Mont d'Haurs Formation contain a highly diversified fauna of stromatoporoids and corals. Thamnophyllum godefroidi and Disphyllum semenoffi are restricted to the base of the outcrop. Cystiphylloides marennense, Atelophyllum emsti and Spinophyllum longiseptatum are present in the first $15 \mathrm{~m}$ of this succession. Numerous other species 


\section{CONVENTIONAL SIGNS}

\begin{tabular}{|c|c|c|c|}
\hline \multicolumn{4}{|c|}{ STROMATOPOROIDS } \\
\hline (2) & MASSIVE & $\odot$ & CRINOIDS \\
\hline \multirow{3}{*}{$\begin{array}{l}\text { TI } \\
Y\end{array}$} & LAMINAR & $\partial$ & BRACHIOPODS \\
\hline & DENDROID & $\theta$ & STRINGOCEPHALIDS \\
\hline & & $\vartheta$ & GASTROPODS \\
\hline \multicolumn{4}{|c|}{ TABULATE CORALS } \\
\hline$\triangle$ & MASSIVE & $\mathrm{P}$ & THIN - BEDDED \\
\hline & LAMINAR & & LIMESTONE \\
\hline & RAMOSE & \begin{tabular}{|l|}
$V \vee V V$ \\
$\vee V \vee V V$ \\
\end{tabular} & DOLOMITE \\
\hline \multicolumn{2}{|c|}{ RUGOSE CORALS } & \begin{tabular}{|c|c|}
-1 \\
-1
\end{tabular} & LIMESTONE \\
\hline & MASSIVE & $-1-1-1$ & ARGILLACEOUS LIMESTONE \\
\hline 9 & FASCICULATE & \begin{tabular}{|l|}
00 \\
111
\end{tabular} & NODULAR LIMESTONE \\
\hline & SOLITARY & VIIID & SHALES \\
\hline
\end{tabular}

Figure 3. Explanation of conventional signs used in Figs 2 and 4.

similar to those of Les Limites quarry have been identified throughout this sequence of $40 \mathrm{~m}$ and their distribution has been figured by Coen-Aubert (2002, fig. 2). Then, the section becomes discontinuous in the upper part of the Mont d'Haurs Formation. But Sociophyllum isactis, S. wedekindi, Temnophyllum majus and Grypophyllum denckmanni, which is more frequent at Wellin than at Les Limites quarry, have been observed up to $43 \mathrm{~m}$ above the base of the thin-bedded limestones.

\subsection{Resteigne quarry (Wellin MC-1974-95; Fig. 2)}

The transition between the Terres d'Haurs and Mont d'Haurs Formations has previously been studied at Resteigne, by CoenAubert (1999, 2000, 2002, 2003). The disused quarry has been located by Coen-Aubert (1996). The situation is similar to that of Les Limites quarry. At the top of the Terres d'Haurs Formation, $14 \mathrm{~m}$ of coarsely crinoidal limestones serve as basement for the reefal limestones from the lower part of the Mont d'Haurs Formation which are only exposed with a thickness of $13.5 \mathrm{~m}$. Spinophyllum spongiosum, Cystiphylloides minimum and Acanthophyllum simplex are present at the top of the Terres d'Haurs Formation. The latter species occurs also in the overlying lithostratigraphic unit together with Sociophyllum wedekindi, Grypophyllum denckmanni, Atelophyllum emsti, Thamnophyllum godefroidi and Spinophyllum longiseptatum.

\subsection{Marenne quarry (Marche-en-Famenne MC-89; Fig. 4)}

The Marenne quarry has been located and investigated by Barchy et al. (2004) who discovered in this excavation an important faulted zone named Marenne Fault. It is a longitudinal and nearly vertical fault more or less aligned along the strike of the layers whose orientation is southwest-northeast. Therefore, the succession Trois-Fontaines, Terres d'Haurs and Mont d'Haurs Formations is repeated and exposed on the south and on the north flanks of this deformation. Before 2012, a continuous section through the Terre d'Haurs Formation and the base of the Mont d'Haurs Formation has been surveyed bed by bed, by the author, in the northeastern part of the Marenne quarry, to the north of the Marenne Fault.

As mentioned by Boulvain et al. (2011), the Terres d'Haurs Formation is about $90 \mathrm{~m}$ thick. The succession is rather similar to that described by Coen-Aubert (2003) and Barchy et al. (2004), in the Hampteau quarry to the south of Hotton. In the Marenne quarry, the lower $46 \mathrm{~m}$ of the Terres d'Haurs Formation are characterized by several levels rich in rugose and tabulate corals; some beds with stringocephalid coquinas or leperditid ostracodes are also present rather low in this sequence. Colonies of Argutastrea quadrigemina (Goldfuss, 1826) have been identified
MARENNE QUARRY (Marche-en-Famenne MC-89)

North of the Marenne Fault

South of the Marenne Fault

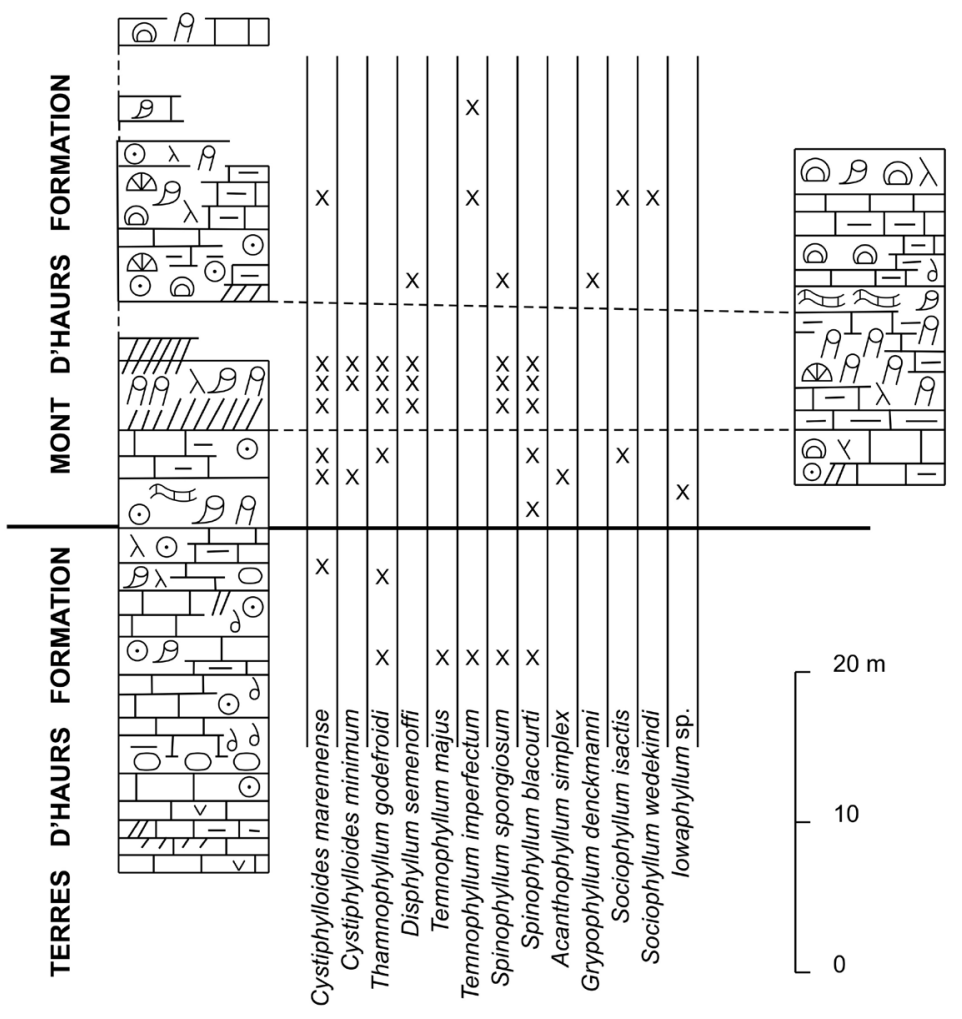

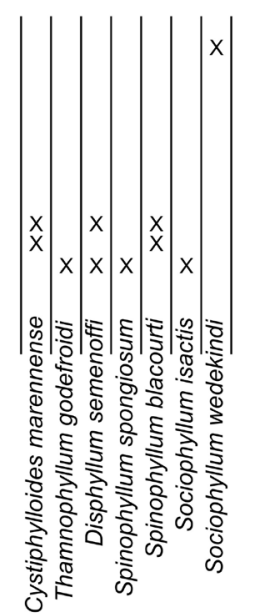

Figure 4. Comparative logs of Marenne quarry to the north and to the south of the Marenne Fault, with the distribution of rugose corals. (For explanation of conventional signs, see Fig. 3). 
up to $43 \mathrm{~m}$ above the base of the lithostratigraphic unit where one specimen of Temnophyllum imperfectum has been collected.

The upper part of the Terres d'Haurs Formation consists of:

- $19.5 \mathrm{~m}$ : fine lagoonal limestones with laminites and leperditid ostracodes.

- $16.5 \mathrm{~m}$ : bioclastic or argillaceous limestones with a few layers of shale; some rugose and tabulate corals at the base.

- $8.5 \mathrm{~m}$ : dark bioclastic or locally argillaceous limestone containing some brachiopods, crinoids, tabulate and rugose corals represented by Cystiphylloides marennense, Thamnophyllum godefroidi, Temnophyllum majus, T. imperfectum, Spinophyllum spongiosum and S. blacourti.

Then, the Mont d'Haurs Formation starts with:

$-3.35 \mathrm{~m}$ : sharp transition to a bioclastic limestone with crinoids and a diverse fauna of massive and laminar stromatoporoids, tabulate and rugose corals. It is probably in this part of the quarry that E. Poty has collected a large colony of Iowaphyllum sp. in 2008.

- $3.1 \mathrm{~m}$ : dark limestone with locally some reef-building organisms as in the preceding unit.

Both of these terms show the same species of rugose corals as at the top of the Terres d'Haurs Formation accompanied by Cystiphylloides minimum, Acanthophyllum simplex and Sociophyllum isactis.

- $1.5 \mathrm{~m}$ : more or less weathered shales.

- $4.55 \mathrm{~m}$ : shales and argillaceous limestones with numerous fasciculate rugose corals associated with solitary rugose corals and dendroid tabulate corals. Occurrence of Disphyllum semenoffi, Thamnophyllum godefroidi, Cystiphylloides marennense, $C$. minimum, Spinophyllum spongiosum and S. blacourti.

$-2.5 \mathrm{~m}$ : gap.

- $9.1 \mathrm{~m}$ : more or less argillaceous limestone with a bed of shale close to the base; rather frequent crinoids and various reef-building organisms with among them S. spongiosum, Cystiphylloides marennense, Disphyllum semenoffi, Temnophyllum imperfectum, Grypophyllum denckmanni, Sociophyllum isactis and $S$. wedekindi.

$-9.7 \mathrm{~m}$ : discontinuous outcrop of limestone with more or less the same facies.

To the south of the Marenne Fault, the shales rich in Cystiphylloides marennense and fasciculate rugose corals, which are present about $8 \mathrm{~m}$ above the base of the Mont d'Haurs Formation, have been already described by Barchy et al. (2004, fig. 3D). With the progress of the quarrying activity in the Marenne quarry, another section in these layers has been investigated by the author (Fig. 4), also to the south of the Marenne Fault. However in this eastern part of the excavation, the remarkable level with numerous fasciculate rugose corals and $C$. marennense is only represented by argillaceous limestones. In the two latter points, the rugose coral fauna of these particular facies is similar to that occurring to the north of the Marenne Fault.

\subsection{Other localities from the south side of the Dinant Synclinorium}

The Bocahut quarry of Glageon in France lying at the western end from the south side of the Dinant Synclinorium has been located and investigated in detail by Boulvain et al. (1995). As mentioned by Coen-Aubert (2000), the Mont d'Haurs Formation has a thickness of $130 \mathrm{~m}$. Several colonies of Disphyllum semenoffi associated with Thamnophyllum godefroidi have been collected $23 \mathrm{~m}$ above the base of the lithostratigraphic unit.

An important part of the Mont d'Haurs Formation is exposed along the road from Han-sur-Lesse to Rochefort and corresponds to the outcrop Han-sur-Lesse MC-1975-15. This section has been located, described and figured by Coen-Aubert (1999, 2000, 2002) who also studied its abundant and varied rugose coral fauna coming mostly from the lower part of the Mont d'Haurs Formation and completed herein by a few specimens of Cystiphylloides marennense, C. minimum and Atelophyllum emsti.

To the east of Marenne, the Marenne Fault has been followed and traced by Barchy et al. (2004), in the area of Ménil-Favay and Hotton. The two outcrops Hotton MC-91 and Hotton MC101 show the shales rich in Cystiphylloides and fasciculate rugose corals which occur in the Marenne quarry, a few metres above the base of the Mont d'Haurs Formation. They are situated to the north of Ménil-Favay and to the north of the Marenne Fault. The outcrop Hotton MC-91 corresponds to the northern end of the Agauche section in the Agauche valley located and described by Barchy et al. (2004, fig. 6). To the north of this exposure, there is a confluence where a tributary arrives on the west side of the Agauche brook. The outcrop Hotton MC-101 is situated along this tributary, $325 \mathrm{~m}$ to the south of the confluence. In both of these small exposures, the rugose coral fauna is represented by Cystiphylloides marennense, Disphyllum semenoffi, Thamnophyllum godefroidi and Spinophyllum blacourti.

The two outcrops Hotton MC-33 and Hotton MC-100 are situated to the south of Hotton and to the south of the Marenne Fault. The base of the Mont d'Haurs Formation with Spinophyllum blacourti and Thamnophyllum godefroidi has been observed at the top of the Hampteau quarry (Hotton MC-33), by CoenAubert (2003) who located this excavation and investigated also the underlying Terres d'Haurs Formation. The outcrop Hotton MC-100 is lying to the north of the Hampteau quarry, along the road to Hotton. It has been located, described and illustrated by Barchy et al. (2004). It is a discontinuous section in the lower part of the Mont d'Haurs Formation which reaches a thickness of about $129 \mathrm{~m}$ and which consists of dark limestone sometimes argillaceous and often rich in various stromatoporoids, tabulate and rugose corals. At the top of this sequence, there is a bed just below the Marenne Fault containing Temnophyllum imperfectum, Acanthophyllum simplex, Grypophyllum denckmanni and Spinophyllum longiseptatum. The other species of rugose corals identified in this section are S. blacourti, Temnophyllum majus and Argutastrea tenuiseptata.

\subsection{South side of the Namur Basin and Vesdre Massif}

On the north side of the Dinant Synclinorium, the south side of the Namur Basin and in the Vesdre Massif, the Mont d'Haurs Formation passes laterally into the Névremont Formation. Bultynck et al. (1991) designated the disused railway section at Aisemont situated on the south side of the Namur Basin and corresponding to the outcrop Tamines MC-1983-2 as stratotype of the lithostratigraphic unit. From that time, the definition of the base of the Névremont Formation has been changed by Coen-Aubert (2000) and Bultynck \& Dejonghe (2002, p. 52). Coen-Aubert $(2000,2002)$ has investigated in detail the continuous section of Aisemont where the Névremont Formation reaches about 71 $\mathrm{m}$ in thickness. Close to its base, there are $12 \mathrm{~m}$ of argillaceous limestones and shales with several levels rich in rugose corals represented by Argutastrea tenuiseptata, Acanthophyllum simplex, Grypophyllum denckmanni, Temnophyllum imperfectum, Spinophyllum spongiosum, S. blacourti and one specimen of $S$. longiseptatum.

Two coralla of Cystiphylloides minimum have been identified in the Givetian from the central and eastern parts of the Vesdre Massif. One of them associated with Sociophyllum isactis comes from the upper part of the Névremont Formation at the outcrop Verviers MC-1974-60 corresponding to the point 13 of Pepinster located and described by Coen-Aubert (1970, 1974). At this locality, the upper $27 \mathrm{~m}$ of this lithostratigraphic unit are characterized by reefal limestones with numerous and various stromatoporoids, rugose and tabulate corals. The other specimen of Cystiphylloides minimum has been observed at the base of the Le Roux Formation overlying the Névremont Formation. It has been found at the depth of $168.4 \mathrm{~m}$ in the borehole Membach 3 (Limbourg 136W1617) investigated by Coen-Aubert et al. (1986) where the Le Roux Formation starts with $4.5 \mathrm{~m}$ of shales containing some nodules of limestone and rugose corals at the base.

\section{Systematic Palaeontology}

The types of the new species and nearly all the figured specimens are stored in the Collection of Palaeontology of the Institut royal des Sciences naturelles de Belgique at Brussels (prefixed IRScNB). However, the specimen of Iowaphyllum sp. is housed in the Collections of Animal and Human Palaeontology of the University of Liège (prefixed ULg.PA).

With the exception of this colony of Iowaphyllum, all the recent material investigated herein has been collected by the 
author in situ, during geological surveys made bed by bed in different localities from the southern part of Belgium (Fig. 1). This sampling is supplemented by a few older thin sections referred in this paper to the "Old collection from the Institut royal des Sciences naturelles de Belgique".

\section{Family Cystiphyllidae Milne-Edwards \& Haime, 1850}

Remark. Pedder (1999, p. 392) has already emphasized the difficulties about the taxonomy of Middle Devonian cystimorph corals. More particularly, it is clear that the large collections from the Middle Devonian of Germany investigated by Wedekind (1922a, 1922b, 1924, 1925) and Birenheide $(1964,1968)$ require an extensive revision which is beyond the scope of the present study.

\section{Genus Cystiphylloides Chapman, 1893}

1893 Cystiphylloides Chapman, p. 46.

1925 Lythophyllum Wedekind, p. 32. 388.

1961 Comanaphyllum Flügel in Flügel \& Flügel (1961), p.

Type species. By original designation and monotypy, Cystiphyllum aggregatum Billings, 1859.

Diagnosis. Fasciculate or predominantly solitary rugose corals. Interior of the corallum filled with vesicular dissepiments and tabellae badly differentiated. Small septal spines absent or rare to more numerous, mostly in the dissepimentarium. Conical stereoplasmic thickenings lacking or weakly to strongly developed, more frequent in the axial zone and present at all growth stages of the corallum. Successive septal cones locally fusing to fill varying amounts of the interior of the corallum. Peripheral globose dissepiments more or less inclined. Axial zone comprising globose tabellae, commonly somewhat larger than the dissepiments, and occasionally incomplete tabulae.

Cystiphylloides marennense $\mathbf{n}$. sp.

(Plate 1A-F; Plate 2F)

Derivation of name. From marennensis, $e$ (Latin) referring to Marenne, type locality of the new species.

Holotype. IRScNB a13394 (= Plate 1A-B). Specimen Marche-en-Famenne MC-89-E145 collected by M. Coen-Aubert in 2007, $10.5 \mathrm{~m}$ above the base of the Mont d'Haurs Formation.

Type locality and horizon. Active quarry of Marenne located by Barchy et al. (2004, fig. 2). Map sheet Marche-en-Famenne 54/8, Lambert coordinates: $\mathrm{x}=224.80$ and $\mathrm{y}=104.475$, southeast side of the Dinant Synclinorium, Belgium. Base of the Mont d'Haurs Formation, top of the Lower Givetian.

Material. 55 specimens with 96 thin sections: Wellin MC1988-6-A711, A713, A714, A717, A789, A793, B94, B95, B99, B153, B158, B160, B169 and B178; Wellin MC-1986-4-A525 and A529; Han-sur-Lesse MC-1975-15-102 and Z944; Marcheen-Famenne MC-89-D894, D898, D910, D911, D912, D913, D915, D916, D958, D959, D960, D998, E115, E116, E117, E118, E120, E127, E133, E145, E146, E147, E148, E149, E150, E179, E180, E182, E260, E261, E262, E264 and E266; Hotton MC91-D527, D529, D531 and D534.

Diagnosis. A solitary species of Cystiphylloides with a mean diameter of $28 \mathrm{~mm}$ to $48 \mathrm{~mm}$. Corallum filled with numerous small dissepiments. Septal spines and weak septal cones rare or lacking.

Description. The material consists of solitary coralla often fragmentary and cylindrical, sometimes conical or ceratoid, whose height varies between $2 \mathrm{~cm}$ and $9.5 \mathrm{~cm}$. Growth lines are occasionally observed whereas the top of a few specimens is affected by rejuvenescence. Some coralla are flattened laterally with an elliptical transverse section. Rare specimens have an excavated calice bordered by steep sides. The outer wall is usually lacking or only present locally. When it is better preserved, it may be encrusted by thin laminar stromatoporoids, alveolitids or auloporids. Some coralla are abraded at the periphery with broken dissepiments at this place in two of them.

The corallum is completely filled with numerous small globose dissepiments. These dissepiments may be broken locally in the dissepimentarium and in the tabularium of several specimens.

In transverse section, septal spines and weak septal cones are frequently rare to absent. In a few coralla, septal spines are sometimes thicker and slightly more developed in the dissepimentarium and occasionally against the outer wall. Small patches of stereoplasmic thickening may occur in the tabularium of rare specimens.

The dissepiments are more or less inclined towards the axis of the corallum though they are sometimes arranged in more or less horizontal layers at the periphery. The axial tabellae are typically vesicular and occasionally larger than the dissepiments; their overall pattern is concave or horizontal. A few weak septal cones are observed in longitudinal section whereas rare septal spines are seen in the dissepimentarium and against the outer wall.

The diameter of the corallum ranges commonly from $26 \mathrm{~mm}$ to $50 \mathrm{~mm}$ and more generally from $20 \mathrm{~mm}$ to $54 \mathrm{~mm}$.

Discussion. The new species is remarkable by its great size and by the near absence of septal spines and sclerocones. This simple structure characterizes also Cystiphylloides aggregatum (Billings, 1859) probably from the Emsian Bois Blanc Formation of Ontario in Canada which is the type species of the genus and whose neotype has been selected and illustrated by McLean (1976). However, C. aggregatum is fasciculate and thus it differs by smaller corallites with fewer dissepiments.

C. marennense shows some similarities with the partial transverse section collected in the Lower Givetian of the Boulonnais, France and assigned by Rohart (1988, pl. 28, fig. 2) to C. conistructum (Quenstedt, 1879). The lectotype of the latter species has been chosen by Birenheide (1964), but it has never been investigated in thin sections. The coralla of $C$. conistructum figured by Birenheide $(1964,1978)$ come from the Upper Eifelian of the Eifel Hills in Germany and they are different from $C$. marennense by the occurrence of weak sclerocones.

There are also some affinities between the new species and the Givetian coralla from the Holy Cross Mountains in Poland referred by Wrzolek (1993) to C. secundum (Goldfuss, 1826) and C. aff. schlueteri (Wedekind, 1922). C. secundum has been revised by Birenheide (1964) without sectioning and studying its holotype. His material from the Middle Devonian of the Eifel Hills is distinguished from C. marennense by some segments of septa and weak septal cones. The lectotype of $C$. schlueteri from the Givetian of Sauerland in Germany has been selected by Birenheide (1964); it is separated from the new species by its rather small size and numerous septal spines against the outer wall.

C. elongatum Stumm, 1962 and C. potterense Stumm, 1962 from the Givetian of Michigan in USA seem to be related to $C$. marennense. However, both species have a narrower tabularium whereas $C$. elongatum differs additionally from $C$. marennense by the occurrence of several horizontal layers of dissepiments at the periphery.

As the new species shows no trace of septa and only rare septal spines, it cannot be assigned to Zonophyllum Wedekind, 1924 whose type species is Z. duplicatum Wedekind, 1924 from the Lower Eifelian of the Eifel Hills. Its lectotype and the original material of Wedekind (1924, figs 6-8) are restricted to a few small transverse sections of rather young stages with short septa. No information is provided about the longitudinal section. Birenheide (1964, p. 21) synonymized Z. duplicatum with Cystiphylloides antilimbatum (Quenstedt, 1879) from the Middle Devonian of the Eifel Hills whose holotype is only known by its external shape. Later on, Birenheide (1978, pp. 176-178) changed his mind and separated the two species. This interpretation was followed by Schröder (1998, pp.71-72). However, Hill (1981, p. F115) continued to consider Zonophyllum duplicatum as synonym of Cystiphylloides antilimbatum. For all these reasons, 
there is clearly some confusion about the definition of the genus Zonophyllum. Several authors such as Merriam (1974), Pedder \& Mclean (1982) and Zhen \& Jell (1996) referred to Zonophyllum species with incomplete septa or with only segments of them. Therefore, Zonophyllum appears to be intermediate between Cystiphylloides and Atelophyllum Wedekind, 1925.

Distribution. The species is only known in the Lower to Middle Givetian from the south side of the Dinant Synclinorium in Belgium. It has been mainly collected by the author in the lower part of the Mont d'Haurs Formation at Ave-et-Auffe, Wellin, Han-sur-Lesse, Marenne and Ménil-Favay; however, a few specimens from Ave-et-Auffe and Marenne come also from the top of the Terres d'Haurs Formation.

\section{Cystiphylloides minimum (Wedekind, 1922)}

(Plate 2G-H; Plate 3E-G)

* 1922a Microplasma minima (n. sp.); Wedekind, p. 62, pl. 2, fig. 5 .

1968 Microplasma minima Wedkind 1921; Birenheide, p.19. 2005 Microplasma minima Wedkind 1921; Schröder, p. 59, pl. 1, fig. 11;

Holotype. Specimen and thin sections WDKD 4510-4511 stored in the Forschungsinstitut Senckenberg at Frankfurt am Main, Germany. Lower Givetian Oberhonsel Formation at Emst near Hagen in North Sauerland, Germany. Pl. 2, fig. 5 in Wedekind (1922a) and pl. 1, fig. 11 in Schröder (2005).

Material. 13 specimens with 20 thin sections: Wellin MC1988-6-A758, B74, B110, B148 and B194; Wellin MC-197495-Z843; Han-sur-Lesse MC-1975-15-106; Marche-en-Famenne MC-89-D426, E124, E167 and E197; Membach borehole 3 (Limbourg 136W1617) at 168.4 m; Verviers MC-1974-60-298.

Diagnosis. A solitary species of Cystiphylloides with a diameter of $15 \mathrm{~mm}$ to $27 \mathrm{~mm}$. Corallum filled with rather large dissepiments. Septal spines and weak septal cones rare or lacking.

Description. The material consists of conical and cylindrical coralla, often fragmentary, whose height varies between $2.5 \mathrm{~cm}$ and $5 \mathrm{~cm}$. Growth lines are only observed in a few specimens. The outer wall is lacking or more or less continuous; it may be locally encrusted by thin laminar stromatoporoids or auloporids. Two coralla are characterized by an elliptical transverse section whereas another one has a wide excavated calice bordered by steep sides.

The corallum is filled with globose dissepiments and tabellae which are usually of rather large size and not very numerous. In transverse section, septal spines and septal cones are frequently absent to rare. In one specimen, there are some small spines at the periphery and against the outer wall. In few other ones, some weak stereoplasmic thickenings are present locally on the dissepiments and in the tabularium.

The dissepiments are inclined towards the axis of the corallum. The axial tabellae are typically vesicular with an overall horizontal pattern. In longitudinal section, the dissepimentarium and the tabularium are rarely affected by weak stereoplasmic thickenings.

The diameter of the corallum ranges from $13 \mathrm{~mm}$ to $29 \mathrm{~mm}$ or $30 \mathrm{~mm}$; it reaches $35 \mathrm{~mm}$ in one specimen.

Discussion. The Belgian material is similar to the holotype of Cystiphylloides minimum which is the only specimen figured by Wedekind (1922a) and Schröder (2005). It differs from $C$. marennense by a much smaller diameter of the corallum, a coarser structure due to the occurrence of rather large dissepiments, typically inclined dissepiments and the horizontal overall pattern of the axial tabellae. C. minimum has been assigned by Wedekind (1922a) and Schröder (2005) to the genus Microplasma Dybowski, 1874 whose type species is M. gotlandicum Dybowski, 1874 from the Wenlock of the Isle of Gotland in Sweden. However, as mentioned among others by Hill (1981) and Zhen \& Jell (1996), Microplasma is represented by fasciculate colonies with short septal spines against the outer wall and dissepiments not well differentiated from axial tabellae.

According to Birenheide (1968), Cystiphylloides minimum is a transitional form between C. tumidum (Flügel, 1961 in Flügel \& Flügel, 1961) and C. macrocystis (Schlüter, 1889). C. tumidum from the Middle Devonian of Turkey is the type species of Comanaphyllum Flügel, 1961 in Flügel \& Flügel (1961) which is considered as synonym of Cystiphylloides by several authors such as McLean (1976). Cystiphylloides tumidum is distinguished from $C$. minimum by weak stereoplasmic thickenings and by dissepiments arranged in horizontal layers at the periphery. $C$. macrocystis is more different. Indeed, it is characterized by a greater size than C. minimum, variable stereoplasmic thickenings on one side of the corallum and the local occurrence of thick and contiguous septa in the dissepimentarium. Its lectotype from the base of the Givetian in the Eifel Hills has been chosen by Birenheide (1964) who did not investigate it in thin sections and figured only a polished longitudinal section.

C. fongi (Yoh, 1937) from the Givetian of Guangxi in China is also a small species of Cystiphylloides without septal cones; however, it is separated from C. minimum by the occurrence of small septal spines against the outer wall.

Distribution. The Belgian material has been mainly collected in the Givetian from the south side of the Dinant Synclinorium: at the top of the Terres d'Haurs Formation and in the Mont d'Haurs Formation at Ave-et-Auffe, Resteigne, Han-sur-Lesse and Marenne. Two coralla come also from the Givetian of the Vesdre Massif: in the upper part of the Névremont Formation at Pepinster and at the base of Le Roux Formation at Membach.

Outside Belgium, Cystiphylloides minimum is only known in the Lower Givetian Oberhonsel Formation from the Sauerland in Germany.

\section{Genus Atelophyllum Wedekind, 1925}

1925 Atelophyllum Wedekind, p. 37.

1925 Dialytophyllum Wedekind, p. 40.

1974 Scissoplasma Spassky \& Kravtsov in Spassky et al. (1974), p. 171.

Type species. By original designation, Mesophyllum emsti Wedekind, 1922.

Diagnosis. Solitary or fasciculate rugose corals. Septa noncarinate, thin to strongly dilated, discontinuous at the periphery where there are discrete carinae. Major septa restricted to the dissepimentarium or extending into the tabularium. Minor septa lacking or variably developed. Sclerocones weak to absent. Peripheral globose dissepiments more or less inclined. Tabularium comprising vesicular tabellae badly differentiated from the dissepiments.

\section{Atelophyllum emsti (Wedekind, 1922) \\ (Plate 2A-C; 3A-D)}

* 1922a Mesophyllum emsti Wdkd.; Wedekind, p. 57, pl. 2, fig. 1.

1925 Atelophyllum emsti Wdkd.; Wedekind, p. 38. 1g-h.

1981 Mesophyllum emsti Wedekind; Hill, p. F127, figs 64,

Holotype. Specimen and thin sections WDKD 4503-4506 and 9729-9730 stored in the Forschungsinstitut Senckenberg at Frankfurt am Main, Germany. Lower Givetian Oberhonsel Formation at Emst near Hagen in North Sauerland, Germany. Pl. 2, fig. 1 in Wedekind (1922a) and figs 64, 1g-h in Hill (1981).

Material. 20 specimens with 38 thin sections: Wellin MC1988-6-A724, A725, A792, B105, B111A, B112, B156, B221, B223, B225 and B249; Wellin MC-1986-4-A507, A509, A510A, A527, A528B, A532B and A534; Wellin MC-1974-95-Z885; Han-sur-Lesse MC-1974-15-Z936. 
Diagnosis. A solitary species of Atelophyllum with 78 to 98 septa at a diameter of $28 \mathrm{~mm}$ to $56 \mathrm{~mm}$. Septa strongly dilated throughout their length. Major septa more or less long, rarely reaching the axis of the corallum. Minor septa lacking to discontinuous.

Description. The material consists of cylindrical, ceratoid and conical coralla which are complete or fragmentary and whose height varies between $2 \mathrm{~cm}$ and $14 \mathrm{~cm}$. Growth lines and rings are rarely observed. The outer wall is rather thick and more or less preserved though it is commonly not continuous. It is frequently encrusted by thin laminar stromatoporoids or even by alveolitids, thamnoporids and fistuliporids.

The septa are non-carinate and strongly dilated throughout their length. They are rarely continuous at the periphery where there are spines against the outer wall and small presepiments with some discrete carinae in a few specimens. The septa may be also thin in this peripheral zone. Then the septa are more or less continuous in the main part of the dissepimentarium.

The major septa are restricted to the dissepimentarium or they are projecting more or less far into the tabularium where they are locally slender or discontinuous. In a few coralla, the major septa usually thick or rarely thin reach at least partially the centre of the tabularium. The minor septa are lacking or more or less represented by segments in the dissepimentarium; in one specimen, they are well developed in its inner part.

In the transverse section of a few specimens, local stereoplasmic thickenings are observed within the dissepimentarium or at the border of the tabularium whereas incomplete rings of stereoplasma occur rarely in the tabularium.

The dissepimentarium consists of 9 to 17 or even 5 to 22 rows of inclined dissepiments often arranged in horizontal layers at the periphery. It is characterized by some long trabeculae and a few spots of fine stereoplasma in its inner and sometimes middle parts. The axial tabellae are typically vesicular with an overall horizontal or occasionally concave pattern. They may be intersected by some segments of usually thick septa. Rare and very weak sclerocones are present in the tabularium.

There are 74 to 100 septa per corallum, but only 66 or 54 in rather young stages. The diameter of the corallum ranges from $20.5 \mathrm{~mm}$ to $64 \mathrm{~mm}$. The width of the tabularium varies between $9 \mathrm{~mm}$ or rarely $6.5 \mathrm{~mm}$ and $20 \mathrm{~mm}$.

Discussion. The Belgian material is similar to the holotype of Atelophyllum emsti which has been figured in transverse and longitudinal sections by Wedekind (1922a) and Hill (1981). A. emsti is the type species of Atelophyllum synonymized with Mesophyllum Schlüter, 1889 by Birenheide (1964) and Hill (1981) and considered as synonym of Lekanophyllum Wedekind, 1924 by Mc Lean (1976). Mesophyllum vesiculosum (Goldfuss, 1826) from the base of the Givetian of the Eifel Hills in Germany and Lekanophyllum punctatum Wedekind, 1924 from the Upper Eifelian of the same area are respectively the type species of the two latter genera and their type specimens are only known in transverse sections (Wedekind, 1924, figs 36-38; Birenheide, 1964, pl. 11, fig. 54; Hill, 1981). According among others to Mc Lean (1976) and Zhen \& Jell (1996), the two genera are mainly distinguished by the development of the discrete carinae at the periphery: abundant in Mesophyllum and rare to absent in Lekanophyllum. In the Belgian material of Atelophyllum emsti, there are some peripheral carinae in a few specimens. For Birenheide (1964, 1968), A. emsti is a synonym of Mesophyllum annulifer (Schlüter, 1885). However in the lectotype of this species chosen by Birenheide (1964), which comes from the base of the Givetian in the Eifel Hills, and in all his illustrated German material, the septa are much thinner than those of Atelophyllum emsti. This taxon is closely related to A. stillei (Wedekind, 1922), A. amanshauseri (Wedekind, 1925) and A. burhenni (Wedekind, 1925) coming also from the Givetian Oberhonsel and Schwelm Formations of North Sauerland. A. stillei and A. amanshauseri have been placed in synonymy with Mesophyllum annulifer by Birenheide $(1964,1968)$, but they are characterized as Atelophyllum emsti by strongly dilated septa. A. burhenni is more different with some stereoplasmic thickening of the septa at the entry of the tabularium.
There are some affinities between $A$. emsti and the Givetian Russian species A. yavorskii (Bulvanker, 1958) from the Kuznetsk Basin and A. parvedivisum (Tsyganko, 1967) from the North Urals, also investigated by Tsyganko (1981). Both taxa were assigned to the genus Dialytophyllum Wedekind, 1925, synonym of Atelophyllum and seem to be separated from A. emsti by major septa mostly restricted to the dissepimentarium.

Distribution. The Belgian material has been collected in the Lower to Middle Givetian from the south side of the Dinant Synclinorium where it comes from the lower part of the Mont d'Haurs Formation at Ave-et-Auffe, Wellin, Resteigne and Hansur-Lesse.

Outside Belgium, Atelophyllum emsti is only known in the Lower Givetian Oberhonsel Formation from the Sauerland in Germany.

Family Phillipsastreidae Roemer, 1883

\section{Genus Thamnophyllum Penecke, 1894}

1894 Thamnophyllum Penecke, p. 593.

1909 Phacellophyllum Gürich, p. 102.

1970 Vestigiphyllum Sytova in Sytova \& Ulitina (1970), p. 117.

1973 Profascicularia Cotton, p. 162.

1981 Thamnophylloides Jin \& He, p. 117.

Type species. By subsequent designation of Lang \& Smith (1935, p. 564), Thamnophyllum stachei Penecke, 1894.

Diagnosis. Fasciculate rugose corals with lateral and axial increase. Septa of two orders, non-carinate or sometimes faintly carinate, more or less long and dilated in the dissepimentarium, thin in the tabularium. Dissepimentarium with one outer row of flat dissepiments and one inner row of horseshoe dissepiments possibly flanked on its axial side, by a few inclined dissepiments. Narrow symmetrical fans of rhipidacanths centred over horseshoe dissepiments. Tabulae complete, incomplete or occasionally compound.

\section{Thamnophyllum godefroidi $\mathrm{n} . \mathrm{sp}$.}

(Plate 4A-G)

Derivation of name. The species is dedicated to Jacques Godefroid, a distinguished specialist of Devonian brachiopods.

Holotype. IRScNB a13405 (= Plate 4A-B). Specimen Wellin MC-1986-4-A506 collected by M. Coen-Aubert in 1986, in the lower part of the Mont d'Haurs Formation.

Type locality and horizon. Disused quarry at Wellin located by Coen-Aubert (1999, fig. 2). Map sheet Wellin 59/6, Lambert coordinates: $\mathrm{x}=203.537$ and $\mathrm{y}=87.462$, south side of the Dinant Synclinorium, Belgium. Lower part of the Mont d'Haurs Formation, top of the Lower Givetian.

Material. 29 specimens with 67 thin sections: Wellin MC1988-6-A703 and B111J; Wellin MC-1986-4-A504, A505 and A506; Wellin MC-1974-95-Z883; Marche-en-Famenne MC89-D388, D390, D873, D888, D891, D892, E114, E129, E134, E135, E136, E141, E154 and E255; Hotton MC-91-D542; Hotton MC-101-D572, D573, D576, D577 and D578; Hotton MC33-C224 and C225; Glageon quarry in France B505.

Diagnosis. A species of Thamnophyllum with 36 to 46 septa at a diameter of $5.5 \mathrm{~mm}$ to $10 \mathrm{~mm}$. Septa rather slightly dilated in the dissepimentarium and leaving an open space in the centre of the tabularium. Rare inclined dissepiments on the inner side of the horseshoe dissepiments.

Description. The material is heterogeneous and consists of more or less fragmentary or dislocated colonies and isolated corallites. The best specimens come from Wellin and Glageon and reach an area of $9 \mathrm{~cm} \times 7 \mathrm{~cm}$ and a height of $10 \mathrm{~cm}$. The 
corallites from the samples of Marenne are often oriented in various directions (Plate 4D) and mixed with corallites of Disphyllum semenoffi and fragments of solitary rugose corals. The isolated cylindrical corallites of Thamnophyllum godefroidi are sometimes ceratoid, curved or broken; they have a height between $1 \mathrm{~cm}$ and $3 \mathrm{~cm}$ and show occasionally longitudinal ribs. The thin outer wall is lacking or partially preserved. A dark median line may be present when the cylindrical corallites are locally in lateral contact. Lateral and axial increase has been observed; tripartite and quadripartite axial offsets occur in some colonies (Plate 4C).

The septa are non-carinate or bear a few spinose and knobbly carinae. They are rather slightly dilated in the dissepimentarium and become thin beyond their entry into the tabularium. A dark median line may affect some septa in the dissepimentarium. Locally, the septa are slender or even discontinuous in the outer zone of flat dissepiments. In transverse section, the pipe of horseshoe dissepiments is occasionally coated with stereome on both sides and rarely bordered by a few inner dissepiments.

The major septa leave a more or less extensive open space in the centre of the corallites; they are only longer in a few specimens. Their axial ends are often discontinuous in the tabularium; some of them are united laterally to form pseudofossulae. The minor septa are restricted to the dissepimentarium or they are hardly projecting into the tabularium where they are sometimes contratingent.

The dissepimentarium consists of one peripheral row of flat dissepiments occasionally concave or intersecting laterally and one row of horseshoe dissepiments with narrow symmetrical fans of rhipidacanths centred over them, in a few specimens. The sides of the horseshoe dissepiments are rarely thickened; they are bordered locally in some corallites, by 1, 2 or even 3 rows of inner and external inclined dissepiments. The tabulae are incomplete and intersecting laterally with rather frequently a flat-topped axial part; they are also horizontal or concave.

There are 34 to 48 septa per corallite; this number reaches 54 in one corallite. The diameter of the corallites ranges from $4.8 \mathrm{~mm}$ to $11 \mathrm{~mm}$. The width of the tabularium varies commonly between $3.5 \mathrm{~mm}$ and $6.5 \mathrm{~mm}$ and more generally between $2.9 \mathrm{~mm}$ and $7.4 \mathrm{~mm}$.

Discussion. The new species resembles Thamnophyllum germanicum Scrutton, 1968 whose lectotype probably from the Givetian of the Eifel Hills in Germany has been revised and figured by Coen-Aubert (1998). This author investigated additionally some Belgian specimens from the Upper Eifelian Jemelle Formation at Wellin. T. germanicum is distinguished from $T$. godefroidi by the weaker dilation of the septa as well as by slightly more septa and inner dissepiments. $T$.godefroidi is also related to T. tsieni Coen-Aubert, 1998 which occurs at Pondrôme and Couvin in the Hanonet Formation, close to the Eifelian-Givetian boundary. T. tsieni is separated by the stronger dilation of the septa, the pipe of the horseshoe dissepiments coated with stereome, the absence of inner dissepiments and a slightly greater septal number.

Rohart (1988, p. 278) assigned to T. caespitosum (Goldfuss, 1826) a few corallites collected in the Lower Givetian of the Boulonnais in France, which are characterized by rather weakly dilated septa as it is the case in some specimens of $T$. godefroidi from Marenne. Rohart (1988) compared also his material with T. germanicum. T. caespitosum is the type species of Phacellophyllum Gürich, 1909 and its holotype from the Givetian of the Bergisches Land in Germany has been illustrated by Birenheide (1969) and Hill (1981). This species differs mainly from Thamnophyllum godefroidi by major septa reaching the centre of the tabularium.

Distribution. The species is only known in the Lower Givetian from the south side of the Dinant Synclinorium in Belgium and at Glageon in France. Besides this locality, it has been collected by the author in the lower part of the Mont d'Haurs Formation at Ave-et-Auffe, Wellin, Resteigne, Marenne, Ménil-Favay and Hotton; however, a few specimens of Marenne come from the top of the Terres d'Haurs Formation.
Family Disphyllidae Hill, 1939

\section{Genus Spinophyllum Wedekind, 1922}

Type species. By monotypy, Campophyllum spongiosum Schlüter, 1889.

Diagnosis. Solitary rugose corals. Septa of two orders, highly and irregularly carinate in the dissepimentarium with yardarm and zigzag carinae. Septa more or less dilated in the dissepimentarium and thin in the tabularium. Possibly some stereoplasmic thickenings within the dissepimentarium. Major septa reaching the axis of the corallum or leaving an open space in the centre of the tabularium. Minor septa traversing the entire dissepimentarium. Dissepimentarium composed of several rows of globose dissepiments arranged in horizontal layers in its outer part and inclined towards the axis of the corallum in its inner part. Tabulae incomplete or compound.

\section{Spinophyllum longiseptatum (Lütte, 1984)}

(Plate 1G; Plate 2D-E; Plate 5D-F)

* 1984 Charactophyllum longiseptatum n.sp.; Lütte, p. 184, fig. 2, pl. 1, figs 5-6, pl. 2, figs 1-2.

1984 Acanthophyllum cf. ultimum (Wedekind, 1922); Lütte, p. 199, fig. 7, pl. 5, figs 5-6.

non 1988 Temnophyllum longiseptatum (Luette 1984); Rohart, p. 275, pl. 35 figs 1-2.

p. 1990 Spinophyllum spongiosum (Schlüter 1889); Birenheide \& Lütte, p. 4, pl. 1, figs 1-3, 5, 9 (non pl. 1, figs 4, 6-8, pl. 2, figs 10-14, pl. 3, figs 15-20).

1994 Spinophyllum longiseptatum (Lütte, 1984); Wrzolek \& Wach, p. 53, pl. 1, figs 1-5.

non 1994 Spinophyllum aff. longiseptatum (Lütte, 1984); Wrzolek \& Wach, p. 55, pl. 1, fig. 6;

2003 Spinophyllum longiseptatum (Lütte, 1984); Fedorowski, p. 96 , pl. 41, figs $4-5$.

2005 Spinophyllum longiseptatum (Lütte, 1985); Schröder, pl. 3 , fig. 8 .

non 2014 Spinophyllum longiseptatum (Lütte, 1984); Abbasi et al., p. 6, pl. 1, fig. 3 .

Holotype. Specimen GIK 961/3 stored in the Palaeontological Collection of the Geological Institute at the University of Köln, Germany. Lower Givetian Kerpen Formation to the north of Girzenberg hill near Keldenich, in the Sötenich Syncline, Eifel Hills, Germany. Fig. 2 and pl. 1, figs 5-6 in Lütte (1984).

Material. 17 specimens with 26 thin sections: Wellin MC1988-6-B9, B66, B219, B220, B225 and B250; Wellin MC1986-4-A508D, A510J and A535E; Wellin MC-1974-95-Z904; Hotton MC-100-D564 and D565: Tamines MC-1983-2-Z55215. Old collection from the Institut royal des Sciences naturelles de Belgique: Agimont (Mont d'Haurs at Givet)-Gi-28646 and 28686; Olloy-sur-Viroin 12 (at Nismes)-Gid-11895 and 12357.

Diagnosis. A species of Spinophyllum with 62 to 70 septa at a diameter of $17 \mathrm{~mm}$ to $23 \mathrm{~mm}$. Septa more or less strongly carinate. Stereoplasmic thickenings present at the adult stage, in various parts of the dissepimentarium.

Description. The material consists of conical, cylindrical and ceratoid coralla which are often fragmentary; their height varies between $1.3 \mathrm{~cm}$ and $4.5 \mathrm{~cm}$. The outer wall is not always well preserved though it is sometimes encrusted by thin laminar stromatoporoids or alveolitids.

The septa bear more or less strong yardarm, spinose and knobbly carinae. They are dilated in the dissepimentarium and usually thin in the tabularium. In a few specimens, the septa are slender at the periphery or throughout their length. Deposits of stereoplasma are more or less developed against the outer wall or within the dissepimentarium where they are occasionally restricted to a narrow ring.

The major septa reach the axis of the corallum or leave an open space in the centre of the tabularium. Their axial ends 
are sometimes twisted in a whorl, forming pseudofossulae or breaking into fragments. The minor septa traverse the entire dissepimentarium or even enter into the tabularium where they may be contratingent; they are rarely shorter or discontinuous at their inner ends.

The dissepimentarium consists of 3 to 12 rows of small globose dissepiments which are arranged in horizontal layers in its inner outer part and inclined in its inner part. They are locally obscured by coarse septal trabeculae which are frequently contiguous. The tabulae are incomplete and intersecting laterally; they may also be vesicular.

There are 56 to 70 septa per corallum; this number is restricted to 50 in one juvenile section. The diameter of the corallum ranges commonly from $10 \mathrm{~mm}$ to $20 \mathrm{~mm}$ and more generally from 7.5 $\mathrm{mm}$ to $23.5 \mathrm{~mm}$. The width of the tabularium varies between 4 $\mathrm{mm}$ and $8.8 \mathrm{~mm}$, but it reaches $12 \mathrm{~mm}$ to $15 \mathrm{~mm}$ in one specimen.

Discussion. The Belgian material of Spinophyllum longiseptatum is similar to the German one figured by Lütte (1984) and Schröder (2005) that is quite often characterized by slightly larger coralla. Zhen \& Jell (1996, p. 77) suggested that the reference of Lütte (1984) about Acanthophyllum cf. ultimum (Wedekind, 1922) should be placed in synonymy with Spinophyllum longiseptatum. Acanthophyllum ultimum is the type species of Neostringophyllum Wedekind, 1922 considered as synonym of Acanthophyllum Dybowski, 1873. A. ultimum is only known by its holotype from the Lower Givetian of the Bergisches Land in Germany which has been figured among others by Hill (1981) and which is devoid of carinae and thickenings in the dissepimentarium. Some German specimens with stereoplasmic thickenings identified as S. spongiosum (Schlüter, 1889) by Birenheide \& Lütte (1990) belong in fact to S. longiseptatum as it was already mentioned by Wrzolek \& Wach (1994) and CoenAubert (2002). The corallum assigned to $S$. aff. longiseptatum by Wrzolek \& Wach (1994) is separated by its weak carination and the absence of stereoplasma in the dissepimentarium. The two specimens illustrated by Rohart (1988) as S. longiseptatum and collected in the Lower Givetian of the Boulonnais in France have few carinae and are probably representatives of Temnophyllum imperfectum Coen-Aubert, 2002 introduced in the Givetian Mont d'Haurs Formation from the Dinant Synclinorium. The corallum described by Abbasi et al. (2014) as Spinophyllum longiseptatum from the Lower Givetian of the Alborz Mountains in Iran is almost not carinate and resembles more $S$. blacourti (Rohart, 1988) occurring in the Lower to Middle Givetian of the Boulonnais and the Dinant Synclinorium.

The holotype and the topotypes of S. ondra Galle, 2007, which come from the Lower Givetian of the borehole Menin-1 in Moravia, Czech Republic, are close to S. longiseptatum, but are distinguished from it by fewer dissepiments and broader tabularia. However, the specimens from the Lower Givetian of another locality in Moravia illustrated by Galle (2007, fig. 6) are very different in having thin septa with rare carinae and no stereoplasmic thickenings.

Zhen \& Jell (1996, variety A p. 77) compared S. longiseptatum to some coralla from the Lower Givetian of North Queensland in Australia showing inner stereozones, but they referred them to $S$. trochoides (Hill, 1942). However, the rest of their material and the holotype of $S$. trochoides figured by Hill (1942) are devoid of these thickenings so that they are related to $S$. spongiosum.

Distribution. The Belgian material sampled by the author comes mainly from the Givetian Mont d'Haurs Formation at Aveet-Auffe, Wellin, Resteigne and Hotton, on the south side of the Dinant Synclinorium. However, one corallum has been collected at the base of the Givetian Névremont Formation in Aisemont, on the south side of the Namur Basin.

Outside Belgium and Givet in France, Spinophyllum longiseptatum is known in the Upper Givetian of the Holy Cross Mountains in Poland and in the Givetian of various areas of Germany such as the Aachen Syncline, the Eifel Hills, the Bergisches Land and the Sauerland.
Family Endophyllidae Torley, 1933

\section{Genus Iowaphyllum Stumm, 1949}

Type species. By original designation, Smithia johanni Hall \& Whitfield, 1873.

Diagnosis. Massive aphroid rugose corals. Non-carinate septa thin in the tabularium and more or less thick in the inner dissepimentarium. Septa continuing across the outer dissepimentarium as dilated septal ridges or crests on the top surfaces of large presepiments which, except at the margin with the tabularium, are arranged in more or less horizontal layers. Major septa reaching the axis of the corallites or leaving an open space in the centre of the tabularium. Minor septa restricted to the dissepimentarium. Tabulae usually incomplete with an elevated axial part.

\section{Iowaphyllum sp.}

(Plate 5A-C)

Material. 1 specimen with 4 thin sections collected by E. Poty: Marenne quarry 2008/4.

Description. The main part of the colony is aphroid with dissepimental tissue between the corallites. But there are also some isolated corallites without any outer wall and presepiments between them (Plate 5B).

The septa are developed in the inner dissepimentarium and in the tabularium. They are non-carinate or bear rare small carinae even in the tabularium. The septa are rather slightly dilated throughout their length or become thin in the tabularium; sometimes, they are slender in the dissepimentarium. The major septa reach the axis of the corallite or leave a more or less extensive open space in the centre of the tabularium where they are occasionally broken into fragments. The minor septa are variable in length traversing all, nearly all or half the dissepimentarium; they are also more or less short, lacking, discontinuous at their peripheral ends or contratingent. Outside the inner dissepimentarium, the corallites are separated by large presepiments and they are sometimes bordered by rather thin and more or less incomplete rings of stereoplasmic thickenings. Such irregular structures with thick septal spines are locally present within the dissepimental tissue.

The dissepimentarium consists of a few rows of large inclined dissepiments separated from the adjacent corallites by a ridge of strongly convex dissepiments. The tabulae are irregular with a more or less flat-topped axial part. They are interrupted by a few segments of septa.

There are 58 to 72 septa per corallite, but only 48 septa in one of them. The diameter of the tabularium varies commonly between $7.5 \mathrm{~mm}$ and $14.5 \mathrm{~mm}$ and more generally between $6 \mathrm{~mm}$ and $17.5 \mathrm{~mm}$. The distances between the centres of adjacent corallites range usually from $24 \mathrm{~mm}$ to $36 \mathrm{~mm}$.

Discussion. Iowaphyllum sp. is related to I. longmenshanense He, 1978 from the Givetian of the Sichuan Province in China. However, the latter species is characterized by smaller quantitative data, major septa reaching systematically the axis of the corallites and minor septa poorly developed. In one of the colonies figured by $\mathrm{He}(1978$, pl. 78, fig. 2), the dissepiments are more or less convex at the border of the tabularium whereas in the other one, they are arranged in horizontal layers as it is usually the case for the genus Iowaphyllum. The longitudinal section of $I$. chucaense Khoa illustrated by Thanh et al. (1988, p. 144, pl. 54, fig. 4) from the Givetian of Northern Vietnam is similar to that of Iowaphyllum sp., but this Asiatic species is different in having fewer septa, narrower tabularia, smaller distances between the centres of adjacent corallites, major septa reaching the axis of the corallites and complete rings of thin stereoplasmic thickening around the outer border of the inner dissepimentarium. Ridges with strongly convex dissepiments between the corallites have been figured by Etheridge (1898) and Zhen (1994) for some specimens of I. schlueteri (Etheridge, 1898) from the Givetian of New South Wales and North Queensland in Australia. 


\begin{tabular}{|c|c|c|c|}
\hline \multicolumn{2}{|c|}{$\begin{array}{l}\text { NORTH SIDE OF THE DINANT } \\
\text { SYNCLINORIUM, SOUTH SIDE OF } \\
\text { THE NAMUR BASIN, VESDRE MASSIF }\end{array}$} & \multicolumn{2}{|c|}{ SOUTH SIDE OF THE DINANT SYNCLINORIUM } \\
\hline $\begin{array}{r}\text { Taghanic Event } \\
\text { I I }\end{array}$ & $\begin{array}{l}\text { LE ROUX } \\
\text { FORMATION }\end{array}$ & $\begin{array}{c}\text { FROMELENNES } \\
\text { FORMATION }\end{array}$ & $\begin{array}{c}\text { Taghanic Event } \\
\text { I I I }\end{array}$ \\
\hline 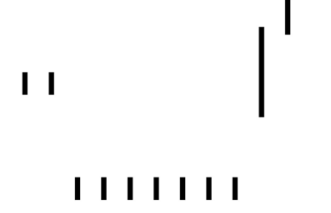 & $\begin{array}{l}\text { NEVREMONT } \\
\text { FORMATION }\end{array}$ & $\begin{array}{c}\text { MONT D'HAURS } \\
\text { FORMATION }\end{array}$ & 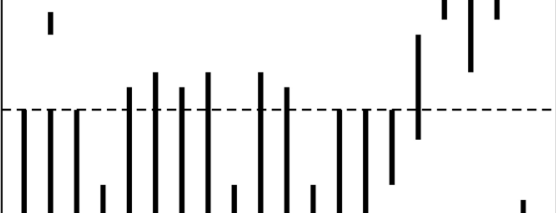 \\
\hline 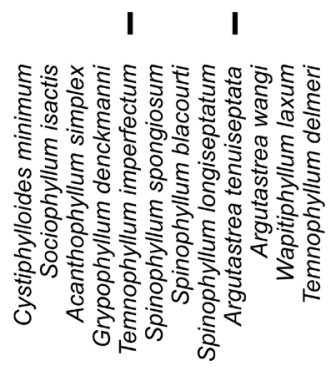 & $\begin{array}{c}\text { RIVIERE } \\
\text { OR } \\
\text { PEPINSTER } \\
\text { FORMATION }\end{array}$ & $\begin{array}{c}\text { TERRES D'HAURS } \\
\text { FORMATION }\end{array}$ & 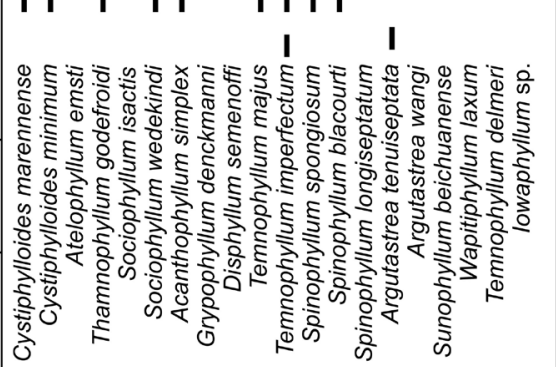 \\
\hline
\end{tabular}

Figure 5. Stratigraphic and geographic distribution of the diverse species of rugose corals identified in the Mont d'Haurs Formation.
Nevertheless, this taxon is distinguished from Iowaphyllum sp. by thick stereoplasmic thickenings at the border of the corallites. Jakubowicz et al. (2019, fig. 13g-i) assigned to Endophyllum sp. a Givetian colony from the Ma'der in Morocco without any intercorallite wall which has several qualitative and quantitative parameters in common with Iowaphyllum sp., but shows dissepiments arranged in horizontal layers between the corallites.

The isolated corallites of Iowaphyllum $\mathrm{sp}$. have some affinities with Blysmatophyllum isisense Pedder, 1970 in Pedder et al. (1970) which is the type species of Blysmatophyllum Pedder, 1970 in Pedder et al. (1970) and which comes from the Givetian of New South Wales. However, this species is separated from the Belgian specimen by broader tabularia, thin septa and long minor septa. As mentioned by Zhen (1994), Blysmatophyllum is a phaceloid to subcerioid genus close to Iowaphyllum.

Distribution. The form is only known close to the base of the Mont d'Haurs Formation, in the Lower Givetian of Marenne, on the south side of the Dinant Synclinorium in Belgium.

\section{Stratigraphic and palaeobiogeographic conclusions}

The material investigated in this paper completes the remarkable biodiversity of the rugose corals (Fig. 5) characterizing the lower part of the Mont d'Haurs Formation (Coen-Aubert, 2002). In Resteigne and Les Limites quarry, the top of the Terres d'Haurs Formation is represented by coarsely crinoidal limestones which serve as basement for the reefal limestones of the Mont d'Haurs Formation. In Marenne, bioclastic limestones play more or less the same role. Then the lower part of the Mont d'Haurs Formation corresponds to fore reef facies often with rather argillaceous limestones very rich in diverse stromatoporoids, tabulate and rugose corals. In the upper part of the lithostratigraphic unit, the limestone becomes pure whereas the reef builders mostly dominated by massive stromatoporoids are scattered in a succession of levels separated by more or less restricted facies. At the top of the Mont d'Haurs Formation, the rugose coral fauna is again more varied and abundant with the opening of the environment. A similar evolution for the lithostratigraphic unit has been observed by Boulvain et al. (2009). These authors consider also the lower part of the Mont d'Haurs Formation as debris flows coming from a reef barrier during major storms or tsunamis. The biodiversity of these deposits is related to this particular facies, their thickness of about $90 \mathrm{~m}$ and their numerous and well-preserved rugose corals which are easy to collect.
At the top of the Terres d'Haurs Formation, several species typical of the Mont d'Haurs Formation are already present; these are Cystiphylloides marennense, C. minimum, Sociophyllum wedekindi, Acanthophyllum simplex, Thamnophyllum godefroidi, Temnophyllum majus, T. imperfectum, Spinophyllum spongiosum and S. blacourti. However, one corallum of Temnophyllum imperfectum has already been found at Marenne, in the middle part of the Terres d'Haurs Formation. Some taxa such as Thamnophyllum godefroidi, Disphyllum semenoffi, Spinophyllum spongiosum and Iowaphyllum sp. occur only rather low in the Mont d'Haurs Formation. Other taxa such as Cystiphylloides marennense, C. minimum, Atelophyllum emsti, Spinophyllum blacourti and $S$. longiseptatum are represented throughout the lower part of the Mont d'Haurs Formation. The same situation concerns Sociophyllum isactis, S. wedekindi, Acanthophyllum simplex, Grypophyllum denckmanni, Temnophyllum majus and T. imperfectum. But these species may extend somewhat higher than the key level of thin-bedded limestones. As for Argutastrea tenuiseptata, it is common in the upper half from the lower part of the Mont d'Haurs Formation, but it has already been observed by Barchy et al. (2004), in the upper part of the Terres d'Haurs Formation at Hotton where it succeeds A. quadrigemina. A. wangi appears below the double level of thin-bedded limestones, but it is more frequent in the upper part of the Mont d'Haurs Formation where it is associated with the first colonies of Wapitiphyllum laxum. This species is more abundant at the top of the Mont d'Haurs Formation where it is accompanied by Sunophyllum beichuanense, Temnophyllum delmeri and rare coralla of Cystiphylloides minimum. The same fauna has been recorded in the lower part of the Fromelennes Formation with the last stringocephalids, up to the Taghanic Event as suggested by Coen-Aubert (2004).

On the north side of the Dinant Synclinorium, the south side of the Namur Basin and in the Vesdre Massif, several species characteristic of the Mont d'Haurs Formation are known in the Névremont Formation which is laterally equivalent (Fig. 5). More particularly, diverse rugose corals have been collected at Aisemont which is the stratotype of the lithostratigraphic unit. Indeed, Argutastrea tenuiseptata, Acanthophyllum simplex, Grypophyllum denckmanni, Temnophyllum imperfectum, Spinophyllum spongiosum, S. blacourti and S. longiseptatum are present close to the base of the Névremont Formation, in its rather argillaceous lower part (Coen-Aubert, 2000). Higher in its upper part consisting of pure limestones with some back reef facies, Argutastrea wangi and Wapitiphyllum laxum appear successively. Sociophyllum isactis and Cystiphylloides minimum have been 
identified at Pepinster, in the upper part of the Névremont Formation where Argutastrea wangi and Wapitiphyllum laxum have been recorded in different localities of the Vesdre Massif. No colony of Argutastrea tenuiseptata has been reported in the Névremont Formation of this structural unit, but the species is represented at Pepinster with Temnophyllum imperfectum and stringocephalids, close to the top of terrigenous deposits belonging to the underlying Pepinster Formation (Bultynck et al., 1991; Bultynck et al., 2000, fig. 9). So it seems that the base of the Névremont Formation is diachronous, which was emphasized for the first time by Bultynck \& Boonen (1976). For these northern facies, it must finally be mentioned that Wapitiphyllum laxum, Temnophyllum delmeri and Cystiphylloides minimum are still occurring with the last stringocephalids, in the lower part of the Le Roux Formation (Coen-Aubert, 2004).

As noted by Coen-Aubert (2002), there are strong affinities between the rugose coral fauna from the Mont d'Haurs Formation and that from the Givetian of Germany. This also the case for Cystiphylloides minimum, Atelophyllum emsti and Spinophyllum longiseptatum described in this paper. S. longiseptatum has been introduced in the Kerpen Formation from the Eifel Hills whereas the holotypes of Cystiphylloides minimum and Atelophyllum emsti come from the Oberhonsel Formation in the North Sauerland. For the Eifel Hills (Fig. 6), the lower part of the Terres d'Haurs Formation corresponds to the Rodert Formation and its upper part to the overlying Kerpen Formation according to Weddige (1996, p. 280; 2000, p. 714) and Coen-Aubert (2011, fig. 4). However, there are some species of rugose corals common to the lower part of the Mont d'Haurs Formation and the Kerpen Formation (Coen-Aubert, 2002). These are besides Spinophyllum longiseptatum, S. spongiosum, Acanthophyllum simplex and Argutastrea tenuiseptata. There are less identifications of rugose corals in the Oberhonsel Formation (Schröder, 2005) so that the comparison with the North Sauerland is not so clear. According to Coen (1985), the Oberhonsel Formation can be correlated with the Terres d'Haurs Formation and the Rodert Formation. But for Weddige (1996, p. 281), it has a larger extension from below the top of the Cürten Formation to the top of the Kerpen Formation. Acanthophyllum simplex, Grypophyllum denckmanni, Temnophyllum majus and Spinophyllum spongiosum, which are known in the lower part of the Mont d'Haurs Formation, are present in the Schwelm Formation overlying the Oberhonsel Formation (Coen-Aubert, 2002).

\begin{tabular}{|c|c|}
\hline $\begin{array}{l}\text { SOUTH SIDE OF THE } \\
\text { DINANT SYNCLINORIUM }\end{array}$ & EIFEL HILLS \\
\hline $\begin{array}{l}\text { MONT D'HAURS } \\
\text { FORMATION }\end{array}$ & BOLSDORF FORMATION \\
\hline \multirow{2}{*}{$\begin{array}{l}\text { TERRES D'HAURS } \\
\text { FORMATION }\end{array}$} & KERPEN FORMATION \\
\hline & RODERT FORMATION \\
\hline \multirow{3}{*}{$\begin{array}{l}\text { TROIS-FONTAINES } \\
\text { FORMATION }\end{array}$} & $\begin{array}{l}\text { DREIMÜHLEN } \\
\text { FORMATION } \\
\end{array}$ \\
\hline & CÜRTEN FORMATION \\
\hline & LOOGH FORMATION \\
\hline HANONET FORMATION & AHBACH FORMATION \\
\hline
\end{tabular}

Figure 6. Correlations between the Givetian lithostratigraphic units from the south side of the Dinant Synclinorium in Belgium and the Eifel Hills in Germany. Data for the Eifel Hills are based on Weddige (1996) and Coen-Aubert (2011).
Additionally, Spinophyllum longiseptatum has been observed by Wrzolek \& Wach (1994) in the Upper Givetian from the Holy Cross Mountains in Poland. Wapitiphyllum laxum is a taxon defined in the same part of the stage in Poland as mentioned by Coen-Aubert (2002). According to this author, the rugose coral fauna of the Mont d'Haurs Formation is mainly restricted to the Old World Realm and is mostly reported in the neighbouring countries of Belgium. Only a few species such as Sociophyllum isactis, Grypophyllum denckmanni and Sunophyllum beichuanense occur far to the east in diverse areas of China and Australia. The colony of Iowaphyllum sp. shows also some affinities with species of the genus represented in the Givetian of these two countries and Vietnam.

Finally, it must be added that Acanthophyllum simplex, Sociophyllum isactis and Spinophyllum spongiosum have been recognized by Coen-Aubert $(2005,2017)$ at the northern margin of Gondwana, in the Givetian of Morocco and Mauritania.

\section{Acknowledgements}

Eddy Poty (Liège) and Julien Denayer (Liège) lent me the colony of Iowaphyllum sp. and provided me all information about this specimen. The thin sections have been made by René Cremers and by Joël Laval at the Laboratory of successively Eddy Poty and Valentin Fischer (Liège). Wilfried Miseur and Thierry Hubin helped me with photography of the corals. Ross McLean and Bernard Mottequin reviewed very carefully the manuscript. I am most grateful to all these people.

\section{References}

Abbasi, M.A., Ashouri, A. \& Khaksar, K., 2014. Solitary rugose corals from the Givetian of the Khoshyeilagh Formation (Eastern Alborz Mountains, NE Iran). Palaeodiversity, 7, 1-21.

Barchy, L., Coen-Aubert, M., Marion, J.M. \& Coen, M., 2004. Mise en évidence de la Faille de Marenne sur la carte géologique Aye - Marche-en-Famenne. Bulletin de l'Institut royal des Sciences naturelles de Belgique, Sciences de la Terre, Supplément, 74, 59-71.

Billings, E., 1859. On the fossil corals of the Devonian rocks of Canada West. The Canadian Journal of Industry, Science and Art, new series, $4,97-140$.

Birenheide, R., 1964. Die « Cystimorpha » (Rugosa) aus dem Eifeler Devon. Abhandlungen der Senckenbergischen Naturforschenden Gesellschaft, 507, 1-120.

Birenheide, R., 1968. Die Typen der Sammlung Wedekind aus der Gattung Plasmophyllum (Rugosa; Mitteldevon). Senckenbergiana lethaea, 49, 1-37.

Birenheide, R., 1969. Typen mittel-und oberdevonischer Rugosa aus der Sammlung Goldfuss. Senckenbergiana lethaea, 50, 37-55.

Birenheide, R., 1978. Rugose Korallen des Devon. In Krömmelbein, K. (ed.), Leitfossilien begründet von G. Gürich. 2., völlig neu bearbeitete Auflage, $n^{\circ}$ 2. Gebrüder Borntraeger, Berlin-Stuttgart, 265 p.

Birenheide, R. \& Lütte, B.P., 1990. Rugose Korallen aus dem MittelGivetium (Mittel-Devon) des Rheinischen Schiefergebirges. Senckenbergiana lethaea, 70, 1-28.

Boulvain, F., Coen-Aubert, M., Mansy, J.L., Proust, J.N. \& Tourneur, F., 1995. Le Givetien en Avesnois (Nord de la France): paléoenvironnements et implications paléogéographiques. Bulletin de la Société belge de Géologie, 103, 171-203.

Boulvain, F., Mabille, C., Poulain, G. \& Da Silva, A.C., 2009. Towards a palaeogeographic and sequential framework for the Givetian of Belgium. Geologica Belgica, 12, 161-178.

Boulvain, F., Coen-Aubert, M., Da Silva, A.C., Kershaw, S., Tourneur, F., Denayer, J., Mottequin, B. \& Poty, E., 2011. 11th International Symposium on Fossil Cnidaria and Porifera Liège 2011. Field Trip 1: Givetian and Frasnian of Southern Belgium. Kölner Forum für Geologie und Paläontologie, 20, 5-49.

Bultynck, P., 2007. Limitations on the application of the Devonian standard conodont zonation. Geological Quaterly, 51, 339-344.

Bultynck, P. \& Boonen, P., 1976. Conodontes des Formations de Rouillon, de Claminforge et de Névremont - Mésodévonien du bord nord du Synclinorium de Dinant. Annales de la Société Géologique de Belgique, 99, 481-509.

Bultynck, P. \& Dejonghe, L., 2002. Devonian lithostratigraphic units (Belgium). Geologica Belgica, 4, 39-69.

Bultynck, P. \& Gouwy, S., 2002. Towards a standardization of global Givetian substages. In Yushkin, N.P., Tsyganko, V.S. \& Mannik, P. (eds), Geology of the Devonian system, Proceedings of the International Symposium, Syktyvkar, Komi Republic, July 9-12, 2002. Geoprint, Syktyvkar, 142-144. 
Bultynck, P., Coen-Aubert, M., Dejonghe, L., Godefroid, J., Hance, L., Lacroix, D., Préat, A., Stainier, P., Steemans, P., Streel, M. \& Tourneur, F., 1991. Les formations du Dévonien moyen de la Belgique. Mémoires pour servir à l'explication des Cartes Géologiques et Minières de la Belgique, 30, 1-105.

Bultynck, P., Coen-Aubert, M. \& Godefroid, J. 2000. Summary of the state of correlation in the Devonian of the Ardennes (Belgium-NE France) resulting from the decisions of the SDS. Courier Forschungsinstitut Senckenberg, 225, 91-114.

Bulvanker, E.Z., 1958. Devonskie chetyrekhluchevye korally okrain Kuznetskogo basseyna. Vsesoyuznyi nauchno-issledovatelskiy Geologicheskiy Institut (VSEGEI), Leningrad, 212 p. [In Russian].

Chapman, E.J., 1893. On the corals and coralliform types of Palaeozoic strata. Proceedings and Transactions of the Royal Society of Canada, 10, section 4, 39-48. https://doi.org/10.5962/bhl.title.38717

Coen, M., 1985. Ostracodes givétiens de l'Ardenne. Mémoires de l'Institut Géologique de l'Université de Louvain, 32, 1-48.

Coen-Aubert, M., 1970. Le Givetien et le Frasnien inférieur de Pepinster. Annales de la Société Géologique de Belgique, 92, 383-395.

Coen-Aubert, M., 1974. Le Givetien et le Frasnien du Massif de la Vesdre. Stratigraphie et paléogéographie. Mémoires in quarto de la Classe des Sciences de 1'Académie Royale de Belgique, $2^{\mathrm{e}}$ série, $18 / 2,1-146$.

Coen-Aubert, M., 1996. Siphonophrentides et Cyathophyllides près de la limite Eifelien-Givetien à Resteigne (Ardenne, Belgique). Bulletin de 1'Institut royal des Sciences naturelles de Belgique, Sciences de la Terre, 66, 19-36.

Coen-Aubert, M., 1998. Thamnophyllides et Acanthophyllides près de la limite Eifelien-Givetien à Wellin et Pondrôme (Belgique). Bulletin de 1'Institut royal des Sciences naturelles de Belgique, Sciences de la Terre, 68, 5-24.

Coen-Aubert, M., 1999. Description de quelques Rugueux coloniaux de la Formation givetienne du Mont d'Haurs en Ardenne. Bulletin de 1'Institut royal des Sciences naturelles de Belgique, Sciences de la Terre, 69, 27-46.

Coen-Aubert, M., 2000. Stratigraphy and additional rugose corals from the Givetian Mont d'Haurs Formation in the Ardennes. Bulletin de 1'Institut royal des Sciences naturelles de Belgique, Sciences de la Terre, 70, 5-23.

Coen-Aubert, M., 2002. Temnophyllids and Spinophyllids (Rugosa) from the Givetian Mont d'Haurs Formation in Belgium. Bulletin de 1'Institut royal des Sciences naturelles de Belgique, Sciences de la Terre, 72, 5-24.

Coen-Aubert, M., 2003. Description of a few rugose corals from the Givetian Terres d'Haurs Formation in Belgium. Bulletin de l'Institut royal des Sciences naturelles de Belgique, Sciences de la Terre, 73, 11-27.

Coen-Aubert, M., 2004. Two new species of Temnophyllids (Rugosa) from the Upper Givetian of Belgium. Bulletin de 1'Institut royal des Sciences naturelles de Belgique, Sciences de la Terre, 74, 19-34.

Coen-Aubert, M., 2005. Rugueux fasciculés et solitaires du Givetien supérieur dans le Tafilalt et le Ma'der (Maroc). Bulletin de l'Institut royal des Sciences naturelles de Belgique, Sciences de la Terre, 75, $67-85$.

Coen-Aubert, M., 2011. Reassignment to the Middle Devonian of some rugose corals investigated by Le Maître (1934) in the Chalonnes Formation from the Southeastern Armorican Massif (France). Bulletin de l'Institut royal des Sciences naturelles de Belgique, Sciences de la Terre, 81, 27-53.

Coen-Aubert, M., 2017. Givetian rugose corals from the Zemmour in Mauritania. Geologica Belgica, 20, 161-180. http://dx.doi. org/10.20341/gb.2017.009

Coen-Aubert, M. \& Lütte, B.P., 1990. Massive rugose corals from the Middle Devonian of the North Eifel Hills (Rheinisches Schiefergebirge, West Germany). Geologica et Palaeontologica, 24, 17-39.

Coen-Aubert, M., Dejonghe, L., Cnudde, C. \& Tourneur, F., 1986. Etude stratigraphique, sédimentologique et géochimique de trois sondages effectués à Membach (Massif de la Vesdre). Service Géologique de Belgique, Professional Paper, 1985/10 (223), 1-57.

Cotton, G., 1973. The rugose coral genera. Elsevier, Amsterdam, 358 p.

Dybowski, W.N., 1873. Monographie der Zoantharia Sclerodermata Rugosa aus der Silurformation Estlands, Nord-Livlands und der Insel Gothland. Archiv für die Naturkunde Liv-, Est- und Kurlands, series $1,5,257-414$.

Dybowski, W.N., 1874. Monographie der Zoantharia Sclerodermata Rugosa aus der Silurformation Estlands, Nord-Livlands und der Insel Gothland. Archiv für die Naturkunde Liv-, Est- und Kurlands, series $1,5,415-532$.

Etheridge, R., 1898. On the occurrence of the genus Endophyllum, Ed. and H. (emend. Schlüter) in the Lower Palaeozoic rocks of N. S. Wales. Records of the Geological Survey of New South Wales, 6, 43-46.
Fedorowski, J., 2003. Typ Coelenterata, Gromada Anthozoa Ehrenberg, 1834, Podgromady: Rugosa Milne Edwards \& Haime, 1850-Dividocorallia Fedorowski, 1991. In Malinowska, L. (ed.), Budowa Geologiczna Polski, tom 3, Atlas Skamienialosci przewodnich i charakterystycznych, czesc 1b-z.1, Dewon. Panstwowy Instytut Geologiczny, Warszawa, 49-124 and Atlas.

Flügel, E. \& Flügel, H., 1961. Stromatoporen und Korallen aus dem Mittel-Devon von Feke (Anti-Taurus). Senckenbergiana lethaea, 42, 377-409.

Frech, F., 1886. Die Cyathophylliden und Zaphrentiden des deutschen Mitteldevon. Palaeontologische Abhandlungen, 3/3, 1-120.

Galle, A., 2007. Spinophyllum Wedekind, 1922 (Anthozoa, Rugosa), in the Lower Givetian (Devonian) of the Bohemian Massif. Bulletin of Geosciences, 82, 133-144. https://doi.org/10.3140/bull. geosci.2007.02.133

Goldfuss, A., 1826. Petrefacta Germaniae 1. Arnz \& Comp., Düsseldorf, $1-76$.

Gouwy, S. \& Bultynck, P., 2003. Conodont based graphic correlation of the Middle Devonian formations of the Ardenne (Belgium): implications for stratigraphy and construction of a regional composite. Revista Espanola de Micropaleontologia, 35, 315-344.

Gürich, G., 1896. Das Palaeozoicum im Polnischen Mittelgebirge. Verhandlungen der Russisch-kaiserlichen Mineralogischen Gesellschaft zu St. Petersburg, serie 2, 32, 1-539.

Gürich, G., 1909. Leitfossilien, Zweite Lieferung: Devon. Gebrüder Borntraeger, Berlin, 97-199.

Hall, J. \& Whitfield, R.P., 1873. Description of new species of fossils from the Devonian rocks of Iowa. Annual Report of the New York State Cabinet of Natural History, 23, 223-239.

He, Y.X., 1978. Subclass Rugosa. In Chengdu Institute of Geology and Mineral Resources (ed.), Atlas of fossils of Southwest China. Sichuan Volume. Part I, From Sinian to Devonian. Geological Publishing House, Beijing, 98-178.

Hill, D., 1939. The Devonian rugose corals of Lilydale and Loyola, Victoria. Proceedings of the Royal Society of Victoria, new series, $51,219-256$.

Hill, D., 1942. The Middle Devonian rugose corals of Queensland, III. Burdekin Downs, Fanning R., and Reid Gap, North Queensland. Proceedings of the Royal Society of Queensland, 53, 229-268.

Hill, D., 1981. Part F, Coelenterata, Supplement 1, Rugosa and Tabulata, 2 vols. In Teichert, C. (ed.), Treatise on Invertebrate Paleontology. The Geological Society of America and The University of Kansas, Boulder (CO) and Lawrence (KS), $762 \mathrm{p}$.

Jakubowicz, M., Krol, J., Zapalski, M.K., Wrzolek, T., Wolniewicz, P. \& Berkowski, B., 2019. At the southern limits of the Devonian reef zone : Palaeoecology of the Aferdou el Mrakib reef (Givetian, eastern Anti-Atlas, Morocco). Geological Journal, 54, 10-38. https://doi. org/10.1002/gj.3152

Jin, S.Y. \& He, J.H., 1981. The Devonian rugose corals of Guangxi, their sequence and systematic descriptions. In Bai, S.L., Jin, S.Y. \& Ning, Z.S. (eds), The Devonian biostratigraphy of Guangxi and adjacent area. Peking University Press, Beijing, 109-148.

Lang, W.D. \& Smith, S., 1935. Cyathophyllum caespitosum Goldfuss and other Devonian corals considered in a revision of that species. The Quarterly Journal of the Geological Society of London, 91, 538-589. https://doi.org/10.1144/GSL.JGS.1935.091.01-04.19

Lütte, B.P., 1984. Rugose Korallen aus dem Mitteldevon (Givetium) der Sötenicher Mulde (Rheinisches Schiefergebirge, Nord-Eifel). Münstersche Forschungen zur Geologie und Paläontologie, 61, 175-243.

McLean, R.A.,1976. Middle Devonian cystiphyllid corals from the Hume Formation, Northwestern Canada. Bulletin Geological Survey of Canada, 274, 1-80. https://doi.org/10.4095/103067

Merriam, C.W., 1974. Lower and Lower Middle Devonian rugose corals of the central Great Basin. U. S. Geological Survey Professional Paper, 805, 1-83. https://doi.org/10.3133/pp805

Milne-Edwards, H. \& Haime, J., 1850. A Monograph of the British Fossil Corals. Part 1, Introduction. The Palaeontographical Society, London, i-lxxxv.

Narkiewicz, K. \& Bultynck, P., 2007. Conodont biostratigraphy of shallow marine Givetian deposits from the Radom-Lublin area, SE Poland. Geological Quaterly, 51, 419-442.

Pedder, A.E.H., 1999. Paleogeographic implications of a Devonian (Givetian, Lower varcus Subzone) rugose coral fauna from the Ma'der Basin (Morocco). Abhandlungen der Geologischen Bundesanstalt, 54, 385-434.

Pedder, A.E.H. \& McLean, R.A., 1982. Lower Devonian cystiphyllid corals from North America and eastern Australia with notes on the genus Utaratuia. Geologica et Palaeontologica, 16, 57-110.

Pedder, A.E.H., Jackson, J.H. \& Ellenor, D.W., 1970. An interim account of the Middle Devonian Timor Limestone of North-Eastern New South Wales. Proceedings of the Linnean Society of New South Wales, 94, 242-272. 
Penecke, K.A., 1894. Das Grazer Devon. Jahrbuch der KaiserlichKöniglichen Geologischen Reichsanstalt, 43, 567-616.

Quenstedt, F.A., 1878-1881. Petrefactenkunde Deutschlands. Sechster Band, Korallen (Röhren- und Sternkorallen). Fues's Verlag (R. Reisland), Leipzig, 1093 p. and Atlas (1879, 145-624).

Roemer, C.F., 1883. Lethaea geognostica. I. Theil, Lethaea palaeozoica. Zweite Lieferung. Stuttgart, 324-543 and Atlas.

Rohart, J. C., 1988. Rugueux givetiens et frasniens de Ferques (Boulonnais-France). In Brice, D. (ed.), Le Dévonien de Ferques. Bas-Boulonnais (N. France). Biostratigraphie du Paléozoïque, 7, 231-297.

Schlüter, C., 1885. Über einige neue Anthozoen aus dem Devon. Verhandlungen des naturhistorischen Vereines der preussischen Rheinlande und Westfalens, 42, 144-151.

Schlüter, C., 1889. Anthozoen des rheinischen Mittel-Devon. Abhandlungen zur geologischen Specialkarte von Preussen und der Thüringischen Staaten, 8/4, 1-207.

Schröder, S., 1998. Rugose Korallen und Stratigraphie des oberen Eifelium und unteren Givetium der Dollendorfer Mulde/Eifel (MittelDevon; Rheinisches Schiefergebirge). Courier Forschungsinstitut Senckenberg, 208, 1-135.

Schröder, S., 2005. Stratigraphie und Systematik rugoser Korallen aus dem Givetium und Unter-Frasnium des Rheinischen Schiefergebirges (Sauerland/Bergisches Land). Zitteliana, B25, 39-116. https://doi. org/10.5282/ubm/epub.12134

Scrutton, C.T., 1968. Colonial Phillipsastraeidae from the Devonian of South-East Devon, England. Bulletin of the British Museum (Natural History), Geology, 15/5, 181-281.

Spassky, N.Ya., Kravtsov, A.G. \& Tsyganko, V.S., 1974. Kolonialnye Tsistimorfy. Trudy Instituta Geologii I Geofiziki, Akademiya Nauk SSSR, Sibirskoe Otdelenie, 201, 170-172. [In Russian].

Stumm, E.C., 1949. Revision of the families and genera of the Devonian tetracorals. The Geological Society of America, Memoir, 40, 1-92. https://doi.org/10.1130/MEM40-p1

Stumm, E.C., 1962. Corals of the Traverse Group of Michigan. Part VII, the Digonophyllidae. Contributions from the Museum of Paleontology The University of Michigan, 17, 215-231.

Sytova, V.A. \& Ulitina, L.M., 1970. Nekotorye pozdneeyfelskie rugozy Zakavkazya. In Astrova, G.G. \& Tchudinova, I.I. (eds), Novye vidy paleozoyskikh mshanok i korallov. Izdatelstvo "Nauka", Moskva, 117-120. [In Russian].

Thanh, T.D., Khoa, N.D., Kromykh, V.G., Hung, N.H., Dzan, N.T. \& Phuong, T.H., 1988. Tselenteraty. In Dubatolov, V.N. (ed.), Stratigrafiya i Tselenteraty Devona Vetnama, tom 2. "Nauka", Novosibirsk, 248 p. [In Russian].

Torley, K., 1933. Über Endophyllum bowerbanki M. Ed. u. H. Zeitschrift der Deutschen Geologischen Gesellschaft, 85, 630-633.

Tsien, H.H., 1978. Rugosa massifs du Dévonien de la Belgique. Mémoires de 1'Institut Géologique de 1'Université de Louvain, 29, 197-229.

Tsyganko, V.S., 1967. Novye predstaviteli chetyrekhluchevykh korallov iz srednego devona severnogo Urala. Trudy Instituta Geologii Komi filiala Akademii Nauk SSSR, 6, 5-13. [In Russian].

Tsyganko, V.S., 1981. Devonskie rugozy Severa Urala. Leningrad, „Nauka“, 220 p. [In Russian].

Walther, C., 1929. Untersuchungen über die MitteldevonOberdevongrenze. Zeitschrift der Deutschen Geologischen Gesellschaft, 80, 97-152.

Weddige, K., 1996. Devon-Korrelationstabelle. Senckenbergiana lethaea, 76, 267-286. https://doi.org/10.1007/BF03042853

Weddige, K., 2000. Devonian Correlation Table. Supplements 2000. Senckenbergiana lethaea, 80, 691-726. https://doi.org/10.1007/ BF03043370

Wedekind, R., 1922a. Beiträge zur Kenntnis der Mesophyllen. Palaeontologische Zeitschrift, 4, 48-63. https://doi.org/10.1007/ BF03041558

Wedekind, R., 1922b. Zur Kenntnis der Stringophyllen des oberen Mitteldevon. Sitzungsberichte der Gesellschaft zur Beförderung der gesamten Naturwissenschaften zu Marburg, 1921/1, 1-16.

Wedekind, 1924. Das Mitteldevon der Eifel. Eine biostratigraphische Studie. I. Teil. Die Tetrakorallen des unteren Mitteldevon. Schriften der Gesellschaft zur Beförderung der gesamten Naturwissenschaften zu Marburg, 14/3, 1-93.

Wedekind, R., 1925. Das Mitteldevon der Eifel. Eine biostratigraphische Studie. II. Teil. Materialien zur Kenntnis des mittleren Mitteldevon. Schriften der Gesellschaft zur Beförderung der gesamten Naturwissenschaften zu Marburg, 14/4, 1-85.

Wrzolek, T., 1993. Rugose corals from the Devonian Kowala Formation of the Holy Cross Mountains. Acta Palaeontologica Polonica, 37, 217-254.

Wrzolek, T. \& Wach, P., 1994. Tetracoral genus Spinophyllum in the Devonian of the Holy Cross Mts, Poland. Geologia, 12/13, 47-63.

Yoh, S.S., 1937. Die Korallenfauna des Mitteldevons aus der Provinz Kwangsi, Südchina. Palaeontographica, Abteilung A, 87, 45-76.
Zhen, Y.Y., 1994. Givetian rugose corals from the northern margin of the Burdekin Basin, north Queensland. Alcheringa, 18, 301-343. https:// doi.org/10.1080/03115519408619501

Zhen, Y.Y. \& Jell, J.S, 1996. Middle Devonian rugose corals from the Fanning River Group, North Queensland, Australia. Palaeontographica, Abteilung A, 242, 15-98.
Manuscript received 27.05.2019, accepted in revised form 30.07.2019, available on line 08.11.2019. 

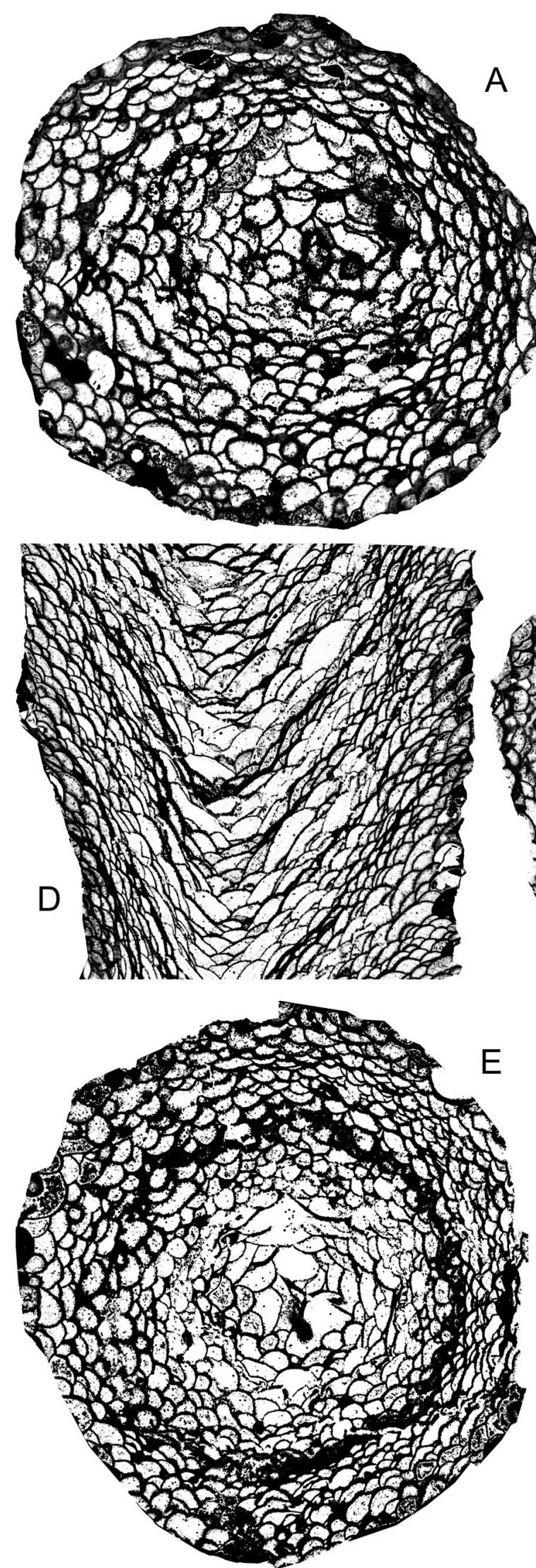
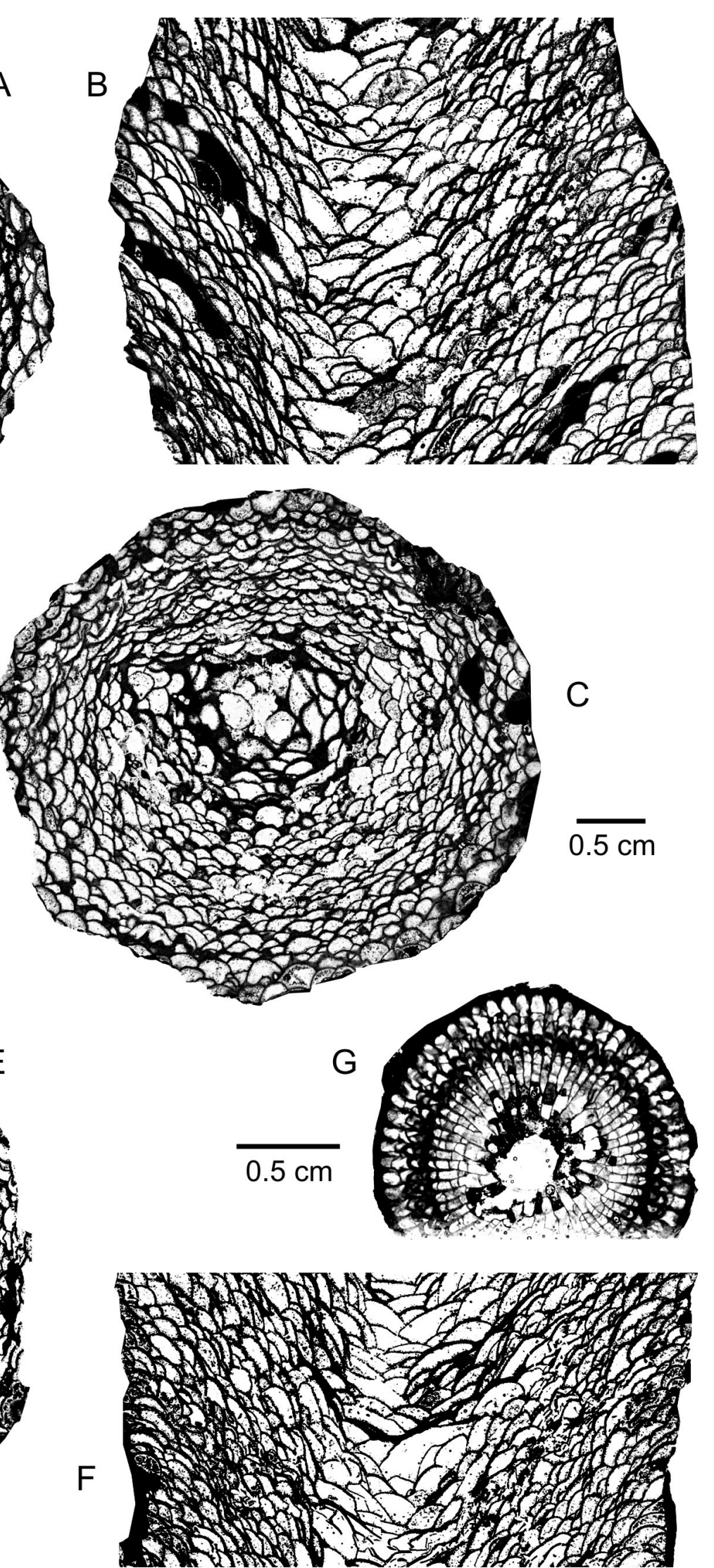

Plate 1. A-F: Cystiphylloides marennense n. sp. A-B: Holotype, IRScNB a13394, Marche-en-Famenne MC-89-E145; transverse and longitudinal sections. C-D: Paratype, IRScNB a13395, Marche-en-Famenne MC-89-E150; transverse and longitudinal sections. E-F: Paratype, IRScNB a13396, Marche-en-Famenne MC-1989-E146; transverse and longitudinal sections. G: Spinophyllum longiseptatum (Lütte, 1984). IRScNB a13410, Wellin MC1986-4-A535E; transverse section. Magnification x 2 for figures A-F and x 3 for figure G. 


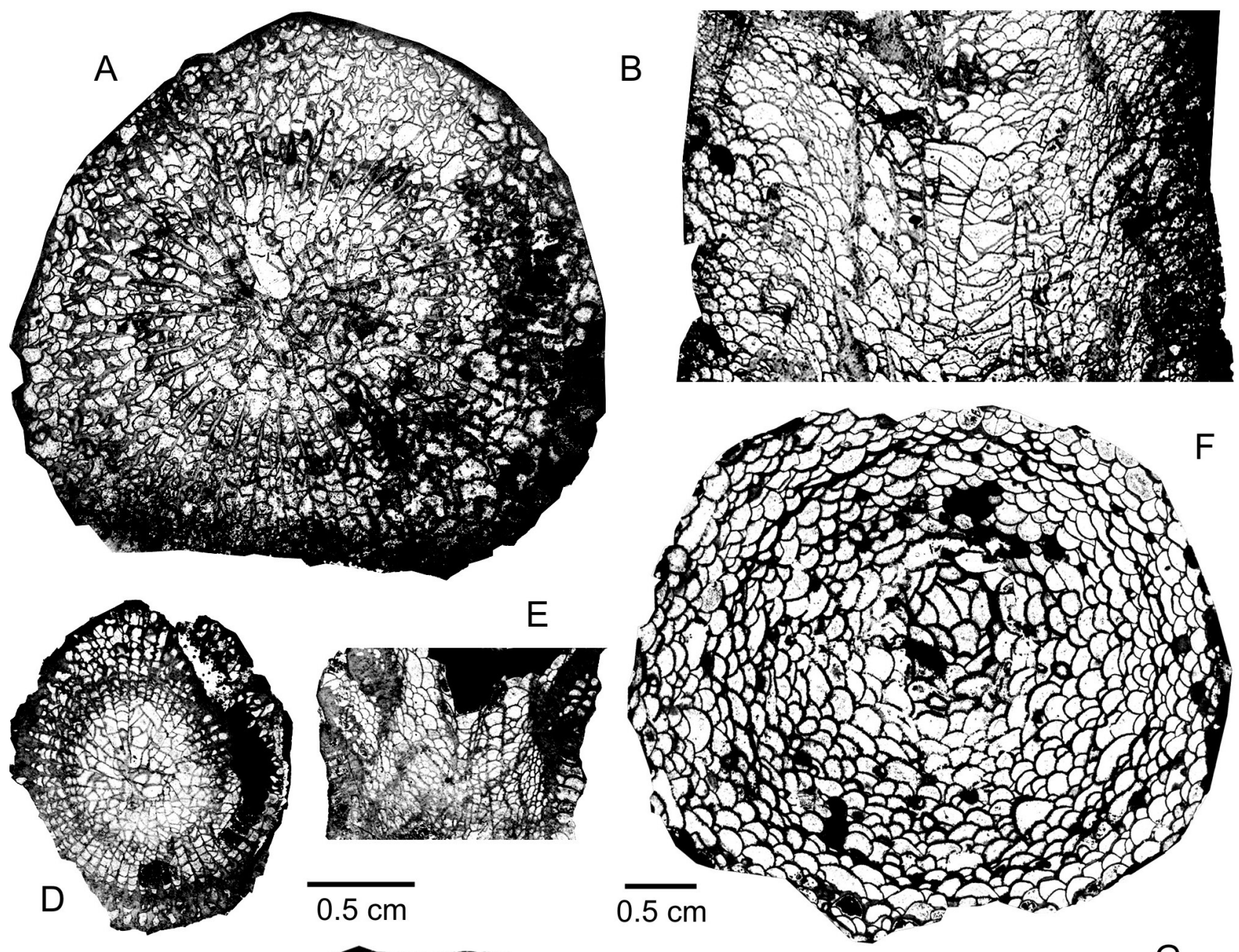

G

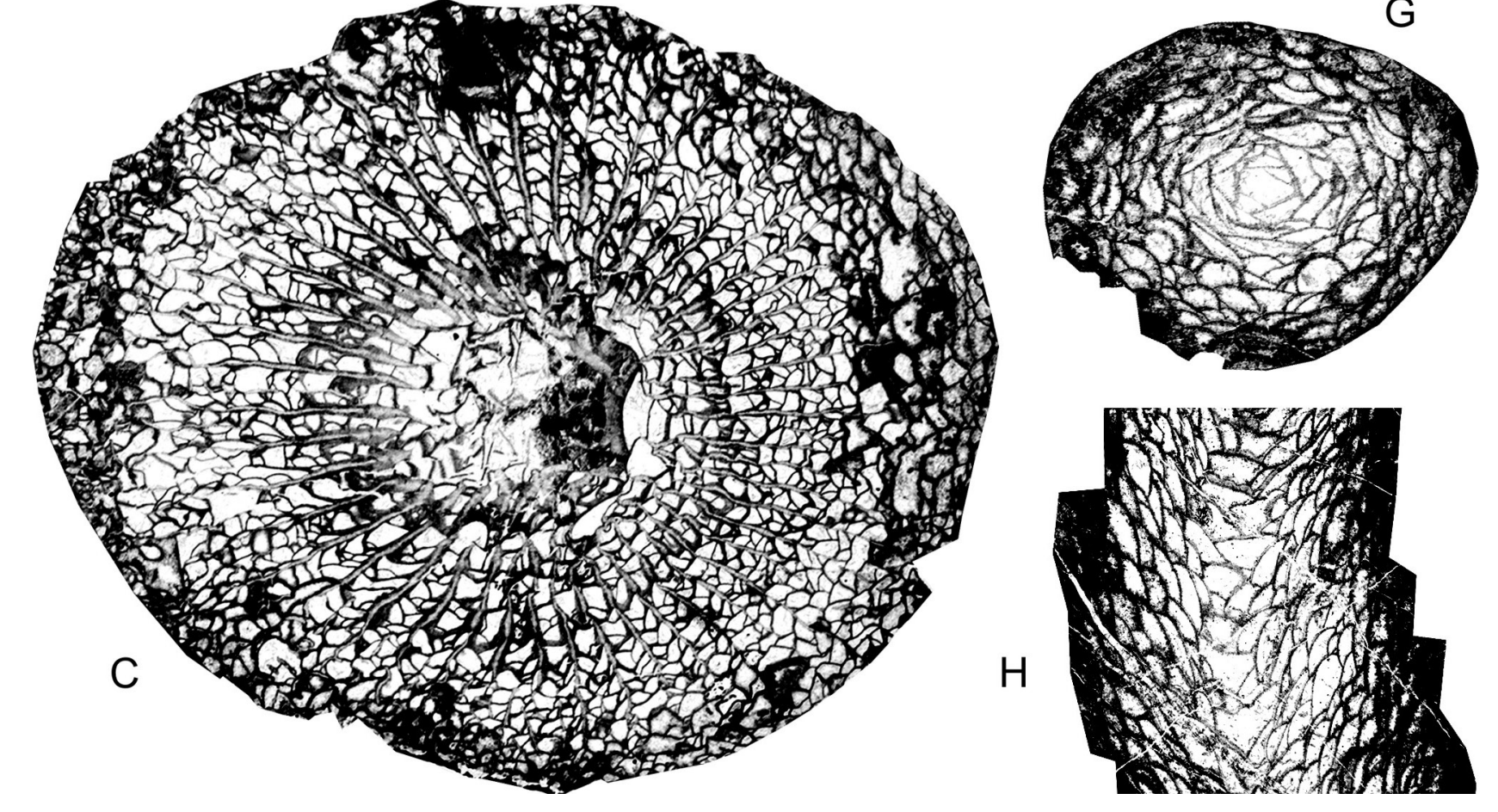

Plate 2. A-C: Atelophyllum emsti (Wedekind, 1922). A-B: IRScNB a13401, Wellin MC-1986-4-A527; transverse and longitudinal sections. C: IRScNB a13402,Wellin MC-1974-95-Z885; transverse section. D-E: Spinophyllum longiseptatum (Lütte, 1984). IRScNB a13411, Wellin MC-1986-4-A510J; transverse and longitudinal sections. F: Cystiphylloides marennense n. sp. Paratype, IRScNB a13397, Marche-en-Famenne MC-89-E180; transverse section. G-H: Cystiphylloides minimum (Wedekind, 1922). IRScNB a13398, Wellin MC-1988-6-B110; transverse and longitudinal sections. Magnification x 2 for figures A-C, F-H and $x 3$ for figures D-E. 

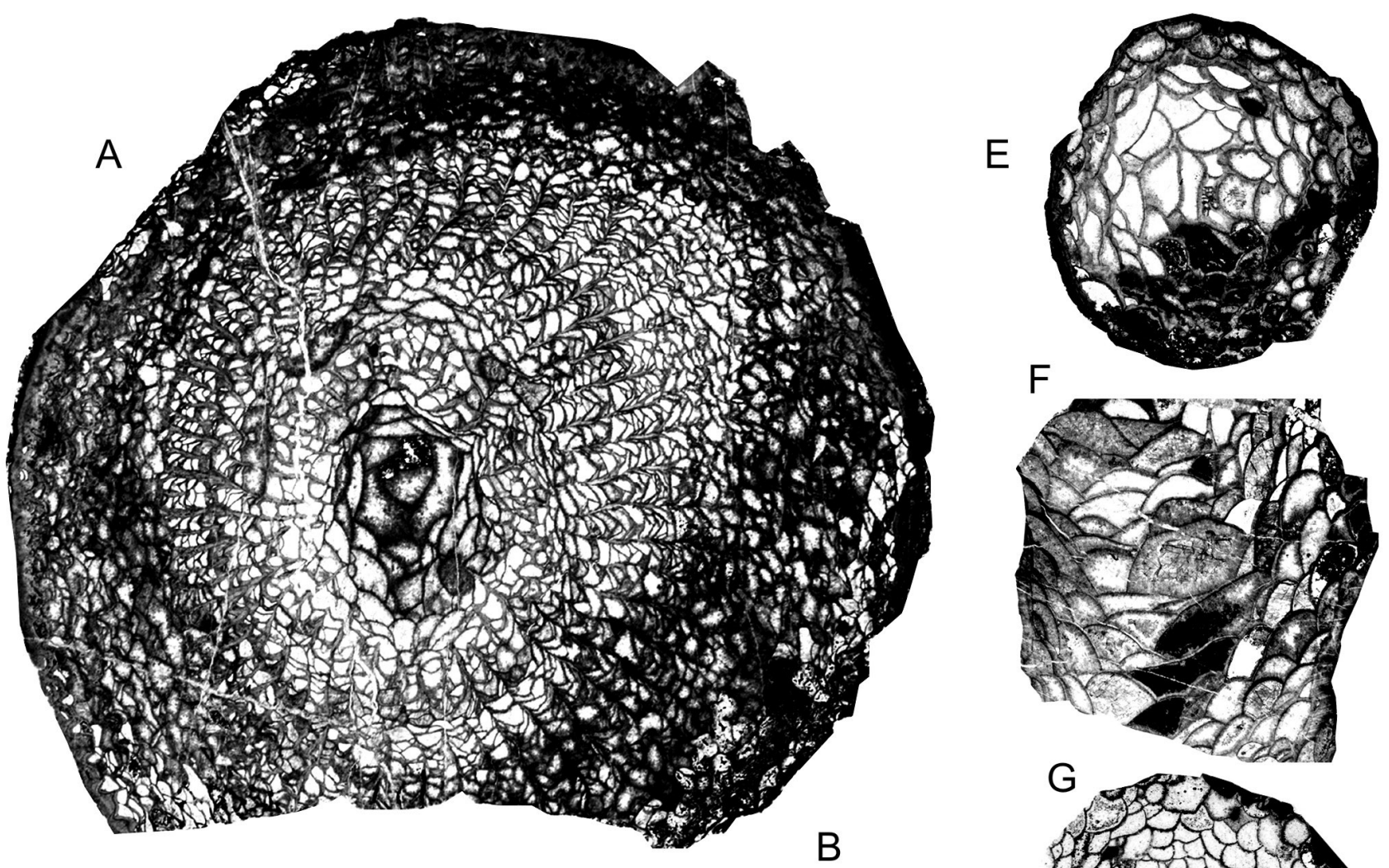

$\mathrm{F}$
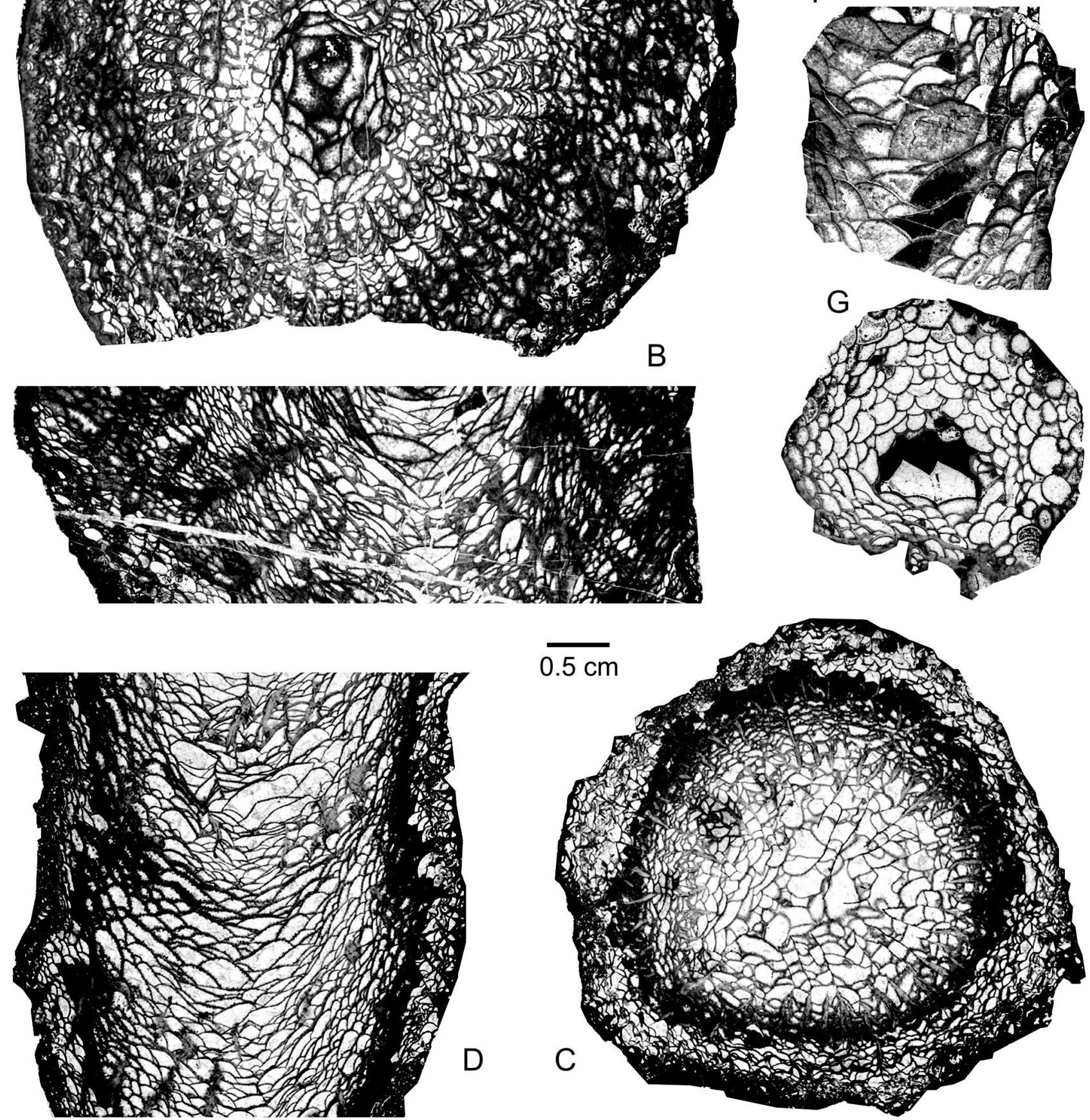

Plate 3. A-D: Atelophyllum emsti (Wedekind, 1922). A-B: IRScNB a13403, Wellin MC-1988-6-A792; transverse and longitudinal sections. C-D IRScNB a13404, Wellin MC-1986-4-A534; transverse and longitudinal sections. E-G: Cystiphylloides minimum (Wedekind, 1922). E-F: IRScNB a13399, Wellin MC-1988-6-A758; transverse and longitudinal sections. G: IRScNB a13400, Marche-en-Famenne MC-89-E197; transverse section. Magnification x 2 . 

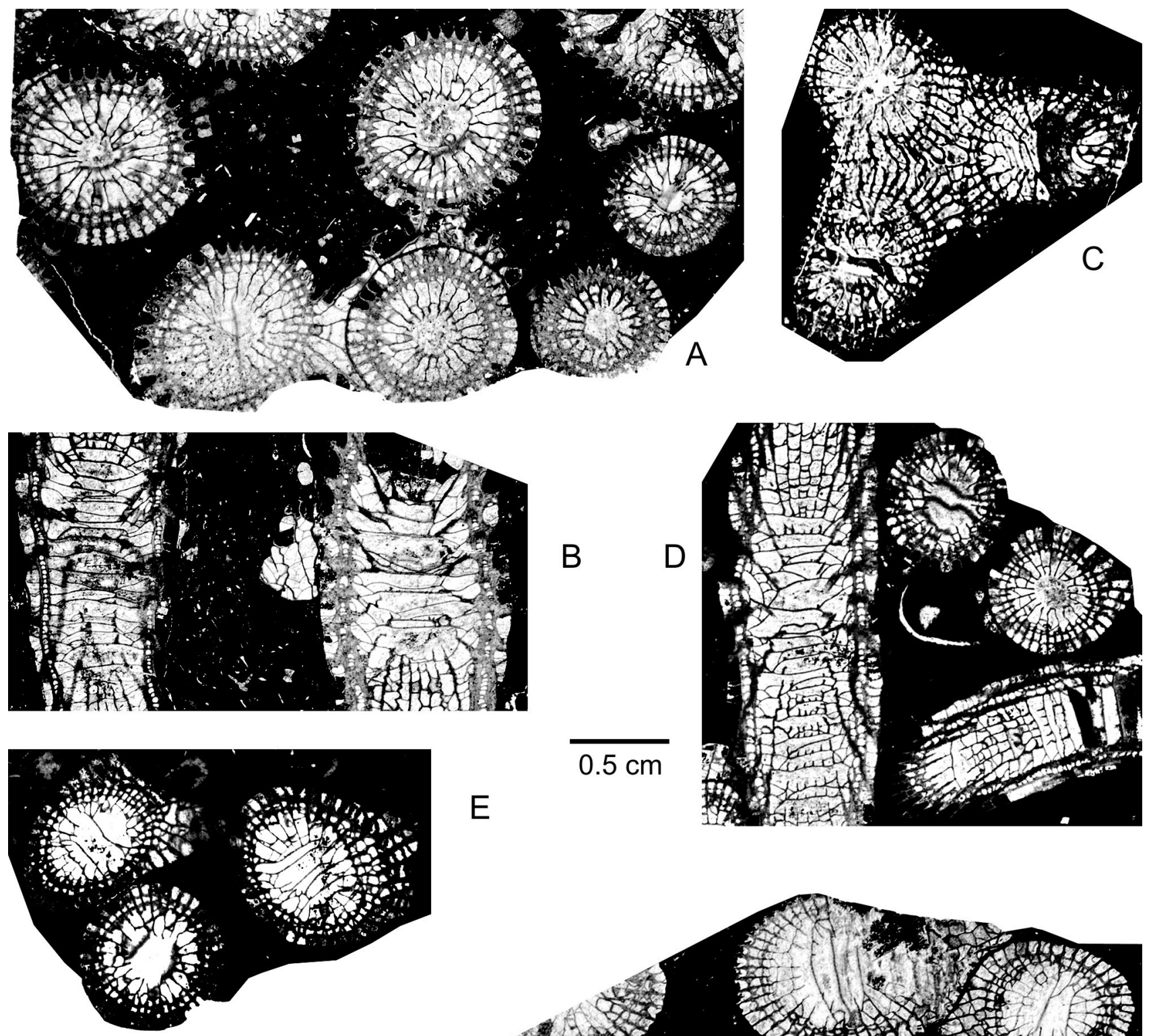

$E$
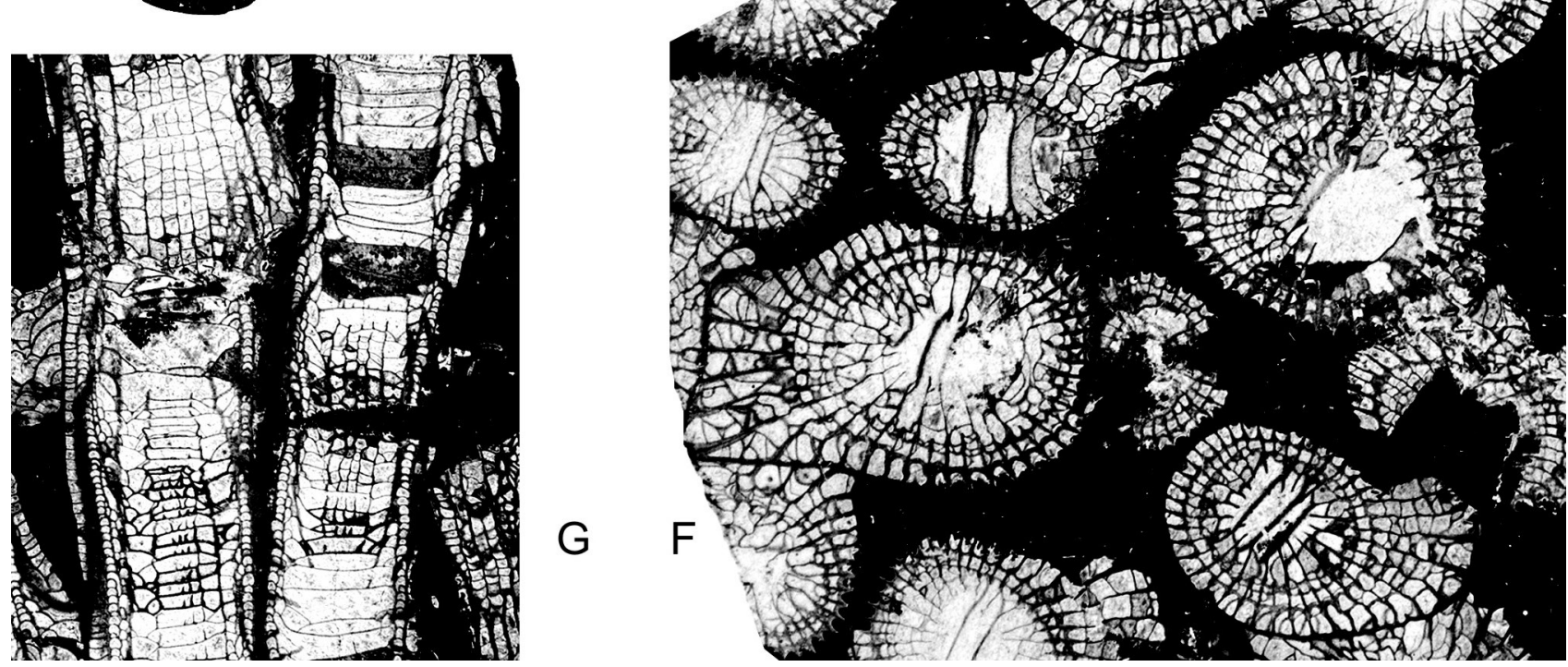

Plate 4. A-G: Thamnophyllum godefroidi n. sp. A-B: Holotype, IRScNB a13405, Wellin MC-1986-4-A506; transverse and longitudinal sections. C: Paratype, IRScNB a13406, Wellin MC-1988-6-A703; transverse section. D: Paratype, IRScNB a13407, Marche-en-Famenne MC-89-E135; transverse and longitudinal sections. E: Paratype, IRScNB a13408, Marche-en-Famenne MC-89-E134; transverse section. F-G: Paratype, IRScNB a13409, Glageon quarry in France B505; transverse and longitudinal sections. Magnification x 3. 


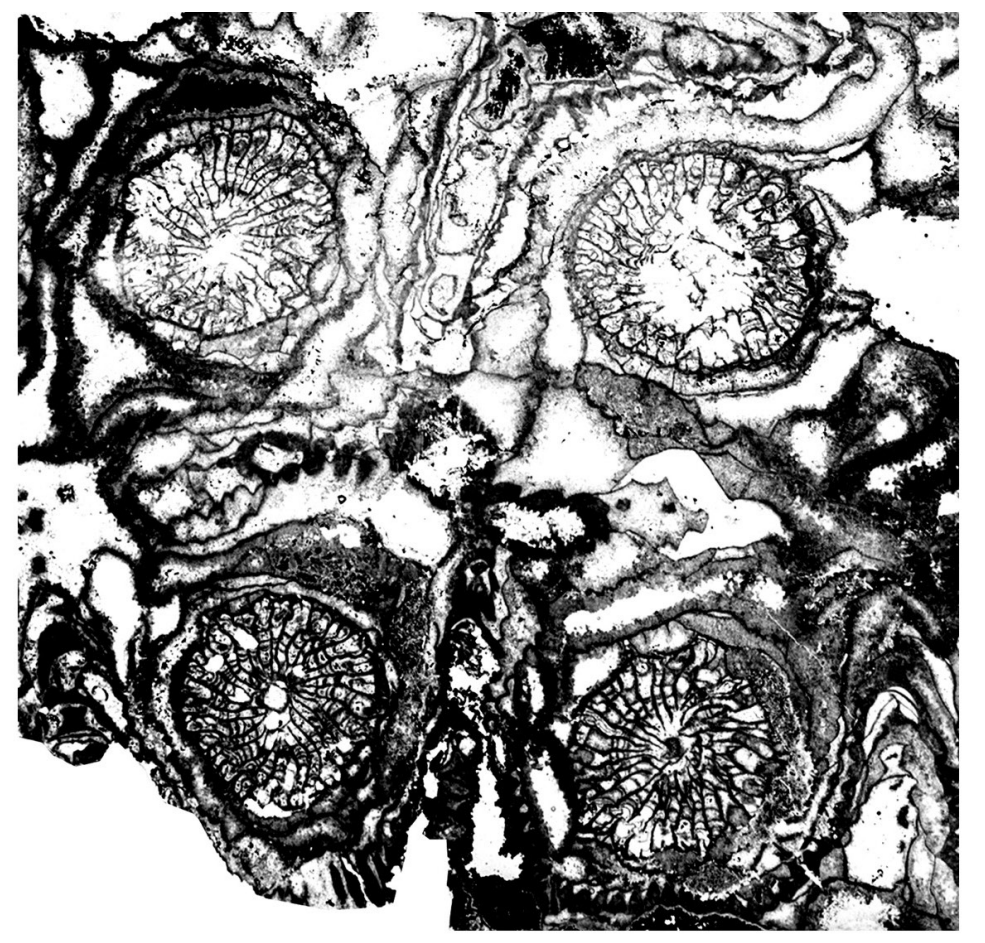

$A$
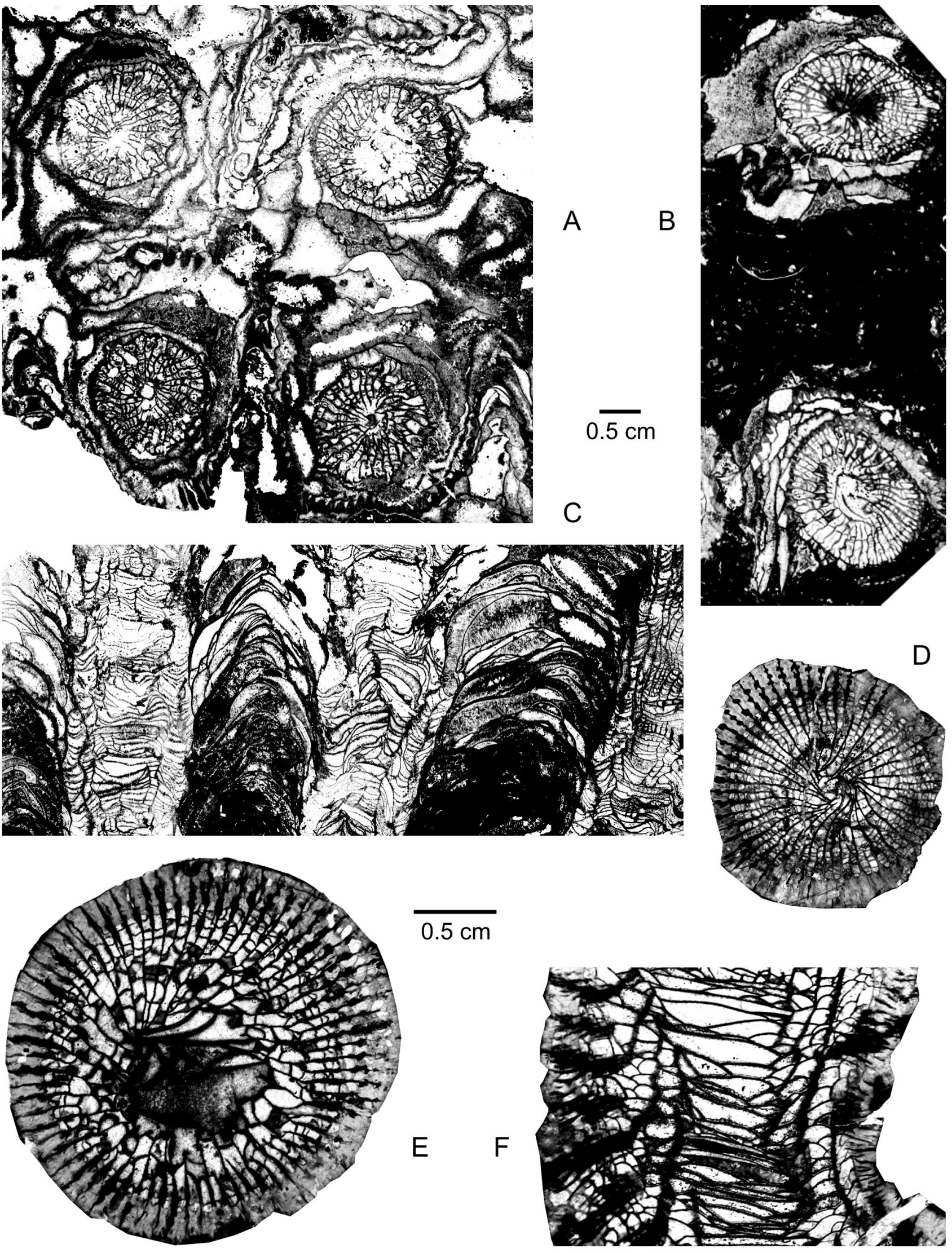

Plate 5. A-C: Iowaphyllum sp. ULg.PA.20190515, Marenne quarry 2008/4; transverse and longitudinal sections. D-F: Spinophyllum longiseptatum (Lütte, 1984). D: IRScNB a13412, Hotton MC-100-D565; transverse section. E-F: IRScNB a13413, Agimont (Mont d'Haurs at Givet)-Gi-28646; transverse and longitudinal sections. Magnification x 1.5 for figures A-C and x 3 for figures D-F. 